\title{
Silicon Improves Yield Performance by Enhancement in Physiological Responses, Crop Imagery, and Leaf and Culm Sheath Morphology in New Rice Line, PadiU Putra
}

\author{
Zulkarami Berahim ${ }^{(D)}{ }^{1}$ Mohamad Husni Omar, ${ }^{1}$ Nurul-Idayu Zakaria, ${ }^{1}$ \\ Mohd Razi Ismail, ${ }^{1,2}$ Rhushalshafira Rosle, ${ }^{3}$ Nor Athirah Roslin, ${ }^{3}$ and Nik Norasma Che'Ya ${ }^{3}$ \\ ${ }^{1}$ Institute of Tropical Agriculture and Food Security, Universiti Putra Malaysia, 43400 Serdang, Selangor, Malaysia \\ ${ }^{2}$ Department of Crop Science, Faculty of Agriculture, Universiti Putra Malaysia, 43400 Serdang, Selangor, Malaysia \\ ${ }^{3}$ Department of Agriculture Technology, Faculty of Agriculture, Universiti Putra Malaysia, 43400 Serdang, Selangor, Malaysia \\ Correspondence should be addressed to Zulkarami Berahim; zulkerami@upm.edu.my
}

Received 11 November 2020; Revised 19 February 2021; Accepted 10 May 2021; Published 1 June 2021

Academic Editor: Mohammed Shahadat Hossain

Copyright () 2021 Zulkarami Berahim et al. This is an open access article distributed under the Creative Commons Attribution License, which permits unrestricted use, distribution, and reproduction in any medium, provided the original work is properly cited.

\begin{abstract}
The PadiU Putra rice line is a blast-resistant and high-yield rice line with high potential. The application of topdressing and the foliar applied method of silicon ( $\mathrm{Si}$ ) treatments could strengthen the culm to resist breakage and ultimately increase yield production. Treatments which consisted of a control, a Si topdressing, and a Si foliar applied were arranged in a randomised complete block design. At 55 days after transplanting (DAT), the foliar applied Si treatments had 59\% higher dry matter partitioning to the roots. Meanwhile, at 75 DAT, both Si foliar applied and topdressing method showed increased assimilate partitioning into the culm sheath by $29 \%$ and $49 \%$, respectively. Dark green and light yellowish colours were obtained in both $\mathrm{Si}$ treatments using UAV, indicating similar results to physiological responses. Remarkably, Si foliar applied treatments enhanced the diameter and width of the outer and inner layers of the diameter of vascular bundles at 75 DAT by 58, 181, and $80 \%$, respectively. The yield production of rice increased by $53 \%$ in the Si foliar applied, compared to the control, and produced a 1.63 benefit-cost ratio.
\end{abstract}

\section{Introduction}

Rice, Oryza sativa L., is a major cereal crop. Sixty per cent of the global population (4.5 billion) lives in Asia, a figure which will increase to 9.3 billion in the year 2050. The demand for rice will also increase by up to $50 \%$ due to the increasing population [1]. In Malaysia, rice is the third most widely planted crop after oil palm and rubber. In 2013, 674,332 hectares (ha) of land was used for plantations with an average yield of only $4.5 \mathrm{tha}^{-1}$ and with a self-sufficiency level (SSL) of $72 \%$ [2]. Following that, the Malaysian government has further targeted an increase in the average paddy yield from $4.5 \mathrm{tha}^{-1}$ to $6.0 \mathrm{tha}^{-1}$ [3]. Recently, a new variety of rice, currently called PadiU Putra, was developed by $[4,5]$, in which resistance genes from the rice variety Pongsu Seribu 2 were pyramided into MR219. This new variety is claimed to be a blast-resistant rice variety with high yield potential and is to be released for commercial cultivation [5]. As a new variety, it is also exposed to the lodging problem due to being a taller plant. Lodging is defined as the permanent displacement of a stem from its upright position [6]. It mostly occurs just before harvest when the plant, in particular the lower portion of the stem, is unable to withstand the weight of the panicle. To date, three types of lodging have been recorded, namely, bending of stems at the base, breakage of stems at any point along the length, and root lodging [7].

The lodging resistance of a rice plant could be achieved through a suitable plant height and shorter basal stems [8]. However, the study conducted by [9] showed that the application of silicon $(\mathrm{Si})$ fertiliser increased the plant height. Leaf and culm morphology can be affected by the application of $\mathrm{Si}$ fertiliser; however, few studies have focused on the structural 
changes to the leaf and culm. The present study and [10-12] provide details on variations in the silica cell structure and $\mathrm{Si}$ deposition process by using scanning electron microscopy (SEM). SEM provides Si localisation in various parts of the rice plant such as the leaf-blade, leaf-sheath, stem, root, and husk. At the same time, the composition and structure of plant cell walls are ideally suited to the functions they perform [11]. The plant cell wall provides mechanical support to cells, tissues, and the entire plant body against lodging that might occur [13]. Sclerenchyma cells, which have both primary and thick secondary walls, provide the major mechanical support in the mature regions of the plant body [11].

$\mathrm{Si}$ is one of the main elements in the Earth's crust, second to oxygen in abundance [14]. Si is primarily present in the epidermal cells which provide structural rigidity to the plant. A remarkable unique feature of $\mathrm{Si}$ is that once it is deposited as silica gel, it is not redistributed to other parts of the plant [15]. Si accumulation sometimes exceeds that of crucial plant nutrients, especially in the grass family [16]. Rice is known as a Si accumulator [17], and the accumulation of Si in leaves and tissues can improve rice growth as a result of increasing the photosynthetic rate [18]. It can also enhance biomass partitioning, improve grain quality $[9,19]$, and increase yield [20]. Si is likely deposited in the cell walls of shoots, the intercellular regions, and silica cells [21]. A mature silica cell with observable $\mathrm{Si}$ deposition is referred to as a silica body. Si is deposited in two types of silica cells in the rice leaf to form two corresponding silica bodies, one dumbbell-shaped and the other bulliform-shaped [21]. The number of silica bodies in shoots correlates positively with the Si content in shoots. Si is also considered an environmentally friendly element in relation to soils, fertilisers, and plant nutrition [22].

The method of fertiliser application is essential as it affects nutrient accessibility. Si was commonly applied as a base fertiliser [9] or foliage fertiliser [23]. Plants absorb Si most effectively when it is applied at the tillering to booting stages [24]. Interestingly, these methods are encouraging for nutrients that are taken up by means of vascular transportation. On the other hand, foliar is relatively easy to apply at manageable rates. However, the topdressing method for solid fertiliser could be supplied at higher rates [10]. In addition, these methods are favourable for nutrients that are taken up by means of vascular transportation. Moreover, the ease of application with Si could also make this form of application more viable and economical [10].

The use of unmanned aerial vehicles (UAVs) for precision agriculture has been increasing, and these machines have been designed specifically to ease problematic agricultural activities [25]. Initially, UAVs were used to take aerial images of a farm [26]. A key advantage of using UAV is that this allows farmers to monitor and obtain valuable information about the field and crop conditions such as crop health, vigour, and growth stages and ultimately to determine yield [27].

Thus, the main objective of this experiment was to examine the topdressing and foliar forms of Si applications on the physiological performance and structural changes of leaf and culm sheaths to enable an evaluation of the yield improvement and a cost analysis of the PadiU Putra rice line.

\section{Materials and Methods}

2.1. Field Experiment and Soil Properties. The field experiment was conducted in major rice granary areas from October 2018 until February 2019. The location of the study was at Kampung Maharaja, Tunjang, Kubang Pasu, Jitra, and Kedah under the Muda Agricultural Development Authority (MADA) $\left(6^{\circ} 16^{\prime} \mathrm{N} 100^{\circ} 21^{\prime} \mathrm{E}, 76 \mathrm{~m}\right.$ elevation). The soil has a clay loam texture (22.9\% sand, $49.1 \%$ silt, and $28 \%$ clay) with pH 5.3 and was used as the cultivation medium. The soil nutrient status was $0.38 \%$ total $\mathrm{N}, 43 \mathrm{mg} \mathrm{kg}^{-1}$ available $\mathrm{P}, 167 \mathrm{mg} \mathrm{kg}^{-1}$ available $\mathrm{K}, 1559 \mathrm{mg} \mathrm{kg}^{-1}$ available $\mathrm{Ca}, 433 \mathrm{mg} \mathrm{kg}^{-1}$ available $\mathrm{Mg}, 529 \mathrm{mg} \mathrm{kg}^{-1}$ available $\mathrm{Fe}, 23 \mathrm{mg} \mathrm{kg}^{-1}$ available $\mathrm{Mn}$, $3.7 \mathrm{mg} \mathrm{kg}^{-1}$ available $\mathrm{Zn}$, and $1.1 \mathrm{mg} \mathrm{kg}^{-1}$ available $\mathrm{Cu}$.

2.2. Planting Materials and Plant Establishment. A transplanted blast-resistant and high-yielding rice line with high potential (MR219 X Pongsu Seribu 1 through SSR markers), known as PadiU Putra, was used in the experiment. The field was thoroughly prepared and levelled using a leveller machine before transplanting took place. Twenty-day-old seedlings were transplanted at $20 \times 15 \mathrm{~cm}$ spacing. Nine plots for each experiment with $1,637 \mathrm{~m}^{2}(24.4 \times 67.1 \mathrm{~m})$ areas were prepared and separated by a $0.5 \mathrm{~m}$ barrier. Each plot was fertilised with NPK compound fertiliser at $360 \mathrm{kgha}^{-1}$, $175 \mathrm{~kg} \mathrm{ha}^{-1}$, and $175 \mathrm{~kg} \mathrm{ha}^{-1}$ at 15,50, and 70 days after transplanting (DAT). Urea was top-dressed at a rate of $100 \mathrm{~kg} \mathrm{ha}^{-1}$ at 35 DAT. In each plot, a uniform plant stand was maintained, and standard agronomic practices were followed, as recommended by government agency practices.

2.3. Experimental Design and Statistical Analysis. In this experiment, treatments comprised two sources of methods of Si application (control treatments/untreated: without any additional Si source; topdressing treatments: plants supplied with $\mathrm{Si}$ in tablet form; and foliar applied treatments: plants supplied with Si through the foliar spray method) were arranged in a randomised complete block design (RCBD) with three replications. Si tablets were supplied by the Behn Meyer AgriCare (M) Company, Malaysia, at a rate of $3 \mathrm{~kg} \mathrm{ha}^{-1}$ at 45 and 65 DAT, corresponding to the vegetative and reproductive stages, respectively. Two thousand and five hundred parts per million of Si foliar application with $0.01 \%$ dimethyl sulfoxide (DMSO) as an adjuvant was performed by spraying plants uniformly to the point of run-off (approximately $140 \mathrm{~L} \mathrm{ha}^{-1}$ ) using a Stihl type mist blower (Stihl Sdn Bhd, Malaysia, 14L) with a constant flow. The treatments were applied between 9:00 to 11:00 am on a day with clear sky at 45 and 65 DAT. Water was maintained at $5 \mathrm{~cm}$ by irrigation throughout the rice cultivation periods, and a $0.5 \mathrm{~m}$ boundary was prepared to avoid assortment. The Statistical Analysis System (SAS 9.2) by least significant different (LSD) at $P \leq 0.05$ was performed.

\subsection{Growth Measurements}

2.4.1. Plant Height and Tiller Number. The plant height was measured according to the methods described by [28], where the measurement was made from the plant base to the tip of the highest leaf blade. The tiller number per square metre was 
counted by a fully expanded tiller. Samples with three replications were taken after ten days of Si treatment had been applied to the plants using all parameters. The purpose of this was to allow enough time for the plants to respond to the treatments. At the same time, two critical times in the rice growth stages were involved in this sampling time, the vegetative and reproductive stages. Four samples per square metre for each treatment were taken randomly and counted at 55 and 75 DAT.

2.4.2. Average Diameter of Internodes and Diameter of Internodes at $20 \mathrm{~cm}$. The average diameter of the internodes was measured at each internode midregion using a digital Vernier caliper from three representative plants from each treatment, with three replications, at 55 and 75 DAT. The diameter of the internodes at $20 \mathrm{~cm}$ was measured at the section of the internodes at 18 to $22 \mathrm{~cm}$ from the basal.

2.5. Photosynthesis, Stomatal Conductance, and Chlorophyll Content. The photosynthesis rate was measured on fully expanded young leaves (the third leaf from the top) at 0900-1100 am on a day with clear sky using a portable photosynthesis system (Li-6400XT, LI-COR, Lincoln, Nebraska, USA). The measurements were taken on the abaxial surface at a $\mathrm{CO}_{2}$ reference rate of $400 \mu \mathrm{mol} \mathrm{m}^{-2} \mathrm{~s}^{-1}$ at 55 and 75 DAT. The photosynthetic photon flux density (PPFD) was $900 \mathrm{mmol} \mathrm{m}^{-2} \mathrm{~s}^{-1}$. The stomatal conductance was derived from the same photosynthesis measurements described earlier. The chlorophyll content of the leaves was measured by the indirect method using a Portable Minolta SPAD 502 Plus chlorophyll meter (Delta T, UK). The third fully expanded leaf from the top was chosen for data measurements at 55 and 75 DAT. Three replications were taken for each of the parameters.

2.6. Biomass Partitioning. Three plants were harvested from each treatment at 55 and $75 \mathrm{DAT}$. They were partitioned into roots, culms, and leaves to determine the dry weights of each part. The dry weights of the plant parts were measured using a digital balance (QC35EDE-S Sartorius, Germany) after drying them in an oven at $72^{\circ} \mathrm{C}$ for three days until the weight became constant. The total biomass was calculated based on the total dry weights of the leaf, culm, root, and total yield. The root to shoot ratio was calculated using the following formula [29]: Root : Shoot Ratio = Total Root Dry Weight $/$ Total Shoot Dry Weight.

2.7. Rice Crop Monitoring Using a Multirotor Unmanned Aerial Vehicle (UAV) and Red, Green, and (RGB) Digital Camera. For aerial imaging, a multirotor UAV DJI Phantom 4 Pro V2.0 with a gimbal-stabilised 4 K60 and 20 megapixel RGB digital camera attached was used to fly above the experimental field area. The flight plan was designed before the data acquisition by using the DroneDeploy software on a tablet. The altitude for the data acquisition of RGB images was set at $80 \mathrm{~m}$, equivalent to a $2.19 \mathrm{~cm}$ spatial resolution. To avoid biased colours and lighting due to cloud shadows, the data collection was conducted in the morning under clear skies and at low wind speed conditions between 08:30 am and 11:00 am local time at 55 and 75 DAT. The camera settings were adjusted according to the light conditions and set to a fixed exposure for each flight.

2.8. Image Processing. Agisoft Metashape Professional software (http://www.agisoft.com/) was used to develop and align the imagery mosaic using Structure from Motion (SfM) algorithms. For each set of images, Agisoft PhotoScan software aligned the images and built point cloud models of the surface. Agisoft allows the generation and visualisation of a dense point cloud model, based on the estimated camera positions, to combine into a single dense point cloud [30]. The software provides a user-friendly process for mosaicking the imagery. The imagery was added and aligned using the Align Photo function. Then, the imagery generated and visualised a dense point cloud model based on the estimated camera position using the Build Dense Cloud function. It calculated the depth information for each camera, which could be combined into a single dense point cloud [30]. The geometrics of the map were reconstructed due to the poor texture of some elements of the scene and noisy or poorly focused images (known as outliers among the points) by using the Build Mesh function. The images were used to build the texture exported as a mosaicked orthophoto image [30]. Finally, the mosaicked orthophoto generated a Digital Surface Model (DSM), and the DSM and orthoimage were imported to build the 2.5 digital models.

2.9. Scanning Electron Microscopy Analysis of Leaf and Culm. At 55 and 75 DAT, the middle section of the flag leaves (approximately $0.5 \mathrm{~cm}$ in width) and the section of internodes at 18 to $22 \mathrm{~cm}$ from the basal (approximately $0.3 \mathrm{~cm}$ in width) from each treatment were cut with a sharp blade and fixed in fixative (4\% glutaraldehyde) for 2 days at $4^{\circ} \mathrm{C}$. The samples were washed in a buffer $(0.1 \mathrm{M}$ sodium cacodylate) with three changes of 30 minutes each. The samples were postfixed in osmium tetraoxide for 2 hours at $4^{\circ} \mathrm{C}$ and were washed again in the buffer $(0.1 \mathrm{M}$ sodium cacodylate) with three changes of 30 minutes each. The samples were then dehydrated in each graded acetone series of 35, 50, 75, and 95\% (30 minutes) and 100\% (1 hour each for three changes) followed by critical point drying (Baltec CPD 030). The leaves and culm specimens were mounted on aluminium stubs, covered with double-sided adhesive tape, and sputter-coated with gold with a sputter coater (Baltec SCD 005). They were viewed under a scanning electron microscope (JEOL JSM 6400, Japan) at an accelerating voltage of $15 \mathrm{kV}$. Three replications were taken for each of the parameters.

2.10. Yield Components, NPV, and BCR. After $80 \%$ grain maturity, all plants were harvested from each plot of treatments in the field trials experiment. Sampling was carried out by harvesting plants at maturity within a quadrant of $1 \mathrm{~m}^{2}$ to determine the yield components. The panicle number of each collected plant was counted to calculate the total number of panicles from the unit area $\left(1 \mathrm{~m}^{2}\right)$. Panicle per hill, grain number per panicle, and percentage of filled grains per panicle were counted and calculated manually. The thousandgrain weight (g) was also obtained using an electronic balance (QC 35EDE-S Sartorius, Germany). Ten panicle-bearing tillers 
TABLe 1: Plant height and tiller number on different Si method applications at 55 and 75 DAT in rice plants.

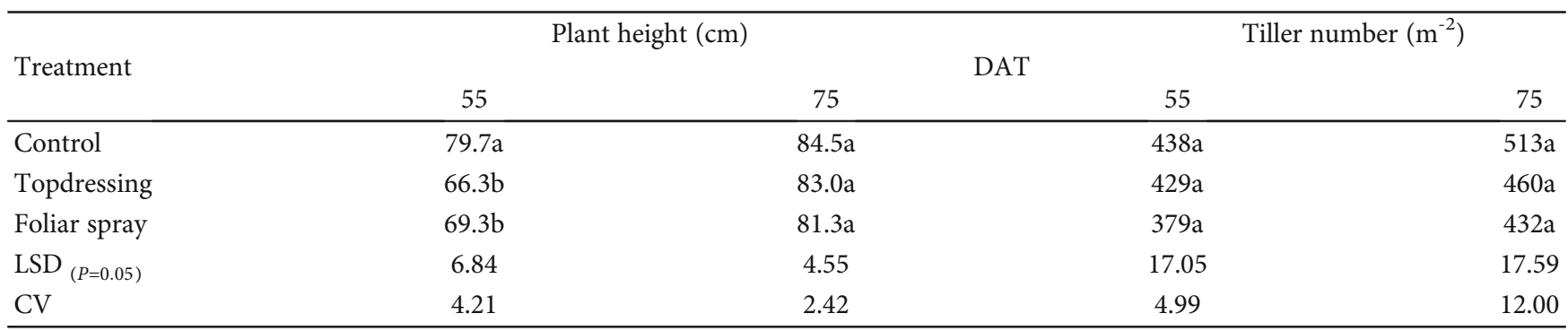

Mean values followed by the same letters within a column are not significantly different at $P \leq 0.05$ by the LSD test. DAT: days after transplanting; CV: coefficient of variation.

TABLE 2: Diameter and length of internodes on different Si method applications at 55 and 75 DAT in rice plants.

\begin{tabular}{|c|c|c|c|c|}
\hline \multirow{2}{*}{ Treatment } & \multicolumn{2}{|c|}{$\begin{array}{l}\text { Diameter of internodes at } 20 \mathrm{~cm} \\
(\mathrm{~mm})\end{array}$} & \multicolumn{2}{|c|}{$\begin{array}{l}\text { Length of internodes } \\
\qquad(\mathrm{mm})\end{array}$} \\
\hline & 55 & 75 & 55 & 75 \\
\hline Control & $2.72 \mathrm{a}$ & $4.9 \mathrm{a}$ & $35.83 \mathrm{~b}$ & $63.74 a$ \\
\hline Topdressing & $2.66 \mathrm{a}$ & $3.5 c$ & $43.85 \mathrm{a}$ & $55.99 b$ \\
\hline Foliar spray & $2.04 a$ & $4.0 \mathrm{~b}$ & $30.51 \mathrm{c}$ & $58.27 \mathrm{~b}$ \\
\hline $\operatorname{LSD}_{(P=0.05)}$ & 0.75 & 0.45 & 5.38 & 3.52 \\
\hline $\mathrm{CV}$ & 13.31 & 4.73 & 7.73 & 2.62 \\
\hline
\end{tabular}

Mean values followed by the same letters within a column are not significantly different at $P \leq 0.05$ by the LSD test. DAT: days after transplanting; CV: coefficient of variation.

from each treatment were sampled. Prior to weighing the grains, fully filled grains were manually separated from the unfilled grains. The percentage of filled grains per panicle was derived from the ratio of the number of fully ripened grains (filled grains) to the total number of grains per panicle per average hill (Yoshida 1981).

The yield was determined with three replications for each treatment at the end of the experiment at 120 DAT. The yield was separately harvested by a harvester machine (World Star, WS70 Plus, China), loaded into separate lorries, and weighed in the rice mills (BERNAS Sdn Bhd). The yield of rice divided by the area in hectares, noted on the purchasing receipt, was collected from the rice mills. Moreover, the Malaysian government gives an additional incentive for every metric ton of rice yield increase, compared with the usual yield per hectare [31]. To determine the economic feasibility of both methods of Si application, a benefit-cost analysis and a net present revenue were carried out. The benefit-cost ratio (BCR) was calculated using the method of [32], whereas the net present value (NPV) was determined as described by [33].

$$
\begin{aligned}
& \text { The benefit }- \text { cost ratio }(\mathrm{BCR})=\text { TCTR, Net present value }(\mathrm{NPV}) \\
& =\Sigma(\mathrm{TR}-\mathrm{TC}) t(1+r) \text { tnt }=1
\end{aligned}
$$

where TC is the total cost, TR is the total revenue, and $r$ is the discount rate of rice field for per season $(t)$. If NR or NPV $>0$, then the total revenue is greater than the total cost; if NR or $\mathrm{NPV}=0$, then the total revenue is equal to the total cost; and if the NR or NPV $<0$, then the total revenue is less than the total cost. In this study, NR and NPV are measured in Malaysian Ringgit (RM) and are based on one hectare. If $B C R>1$, then the total revenue is greater than the total cost; if $\mathrm{BCR}=$ 1 , then the gross revenue is equal to the total cost; and if the $\mathrm{BCR}<1$, then the gross revenue is less than the total cost.

\section{Results}

\subsection{Plant Growth Parameters}

3.1.1. Plant Height and Tiller Number. The plant height and tiller number per square metre for different Si method applications at 55 and 75 DAT in rice plants are shown in Table 1. The results showed that the use of Si foliar applied and topdressing treatments showed significantly reduced plant height by 17 and 13\% at 55 DAT, respectively, compared to the control. The results further revealed that both methods of Si treatments imposed caused slight differences in plant height during the reproductive stages of the rice plant (75 DAT). According to the results, the tiller number of both methods of Si treatments was not statistically different from the control at both DAT.

3.1.2. Diameter and Length of Internodes. The diameter of internodes was not statistically significant among treatments at 55 DAT (as shown in Table 2). The diameter of internodes was significantly different at 75 DAT in the control, followed by the Si foliar applied and topdressing treatments, with 4.9, 4.0 , and $3.5 \mathrm{~mm}$, respectively. On the other hand, the length of internodes for Si topdressing treatments was significantly different, by $22 \%$, at 55 DAT compared to the other 
TABLE 3: Photosynthesis rate, stomatal conductance, and relative chlorophyll content from different Si method applications at 55 and 75 DAT in rice plants.

\begin{tabular}{|c|c|c|c|c|c|c|}
\hline \multirow[t]{2}{*}{ Treatment } & \multicolumn{2}{|c|}{$\begin{array}{l}\text { Photosynthesis rate } \\
\left(\mu \mathrm{mol} \mathrm{CO} \mathrm{m}^{-2} \mathrm{~s}^{-1}\right)\end{array}$} & \multicolumn{2}{|c|}{$\begin{array}{c}\text { Stomatal conductance } \\
\left(\mathrm{mmol} \mathrm{H}_{2} \mathrm{O} \mathrm{m} \mathrm{m}^{-2} \mathrm{~s}^{-1}\right) \\
\text { DAT }\end{array}$} & \multicolumn{2}{|c|}{$\begin{array}{l}\text { Relative chlorophyll } \\
\text { content (SPAD value) }\end{array}$} \\
\hline & 55 & 75 & 55 & 75 & 55 & 75 \\
\hline Control & $8.7 b$ & $17.8 \mathrm{a}$ & $111.0 \mathrm{~b}$ & $314.7 \mathrm{a}$ & $29.5 b$ & $34.6 \mathrm{a}$ \\
\hline Topdressing & $11.3 \mathrm{a}$ & $16.2 \mathrm{~b}$ & $183.0 \mathrm{a}$ & $269.0 \mathrm{a}$ & $26.6 b$ & $31.2 \mathrm{a}$ \\
\hline Foliar spray & $11.0 \mathrm{a}$ & $15.8 \mathrm{~b}$ & $102.9 \mathrm{~b}$ & $218.5 a$ & $32.5 a$ & $35.6 \mathrm{a}$ \\
\hline $\operatorname{LSD}_{(P=0.05)}$ & 2.03 & 1.34 & 12.58 & 18.16 & 5.23 & 3.53 \\
\hline $\mathrm{CV}$ & 8.69 & 3.55 & 4.19 & 12.89 & 3.61 & 4.61 \\
\hline
\end{tabular}

Mean values followed by the same letters within a column are not significantly different at $P \leq 0.05$ by the LSD test. DAT: days after transplanting; CV: coefficient of variation.

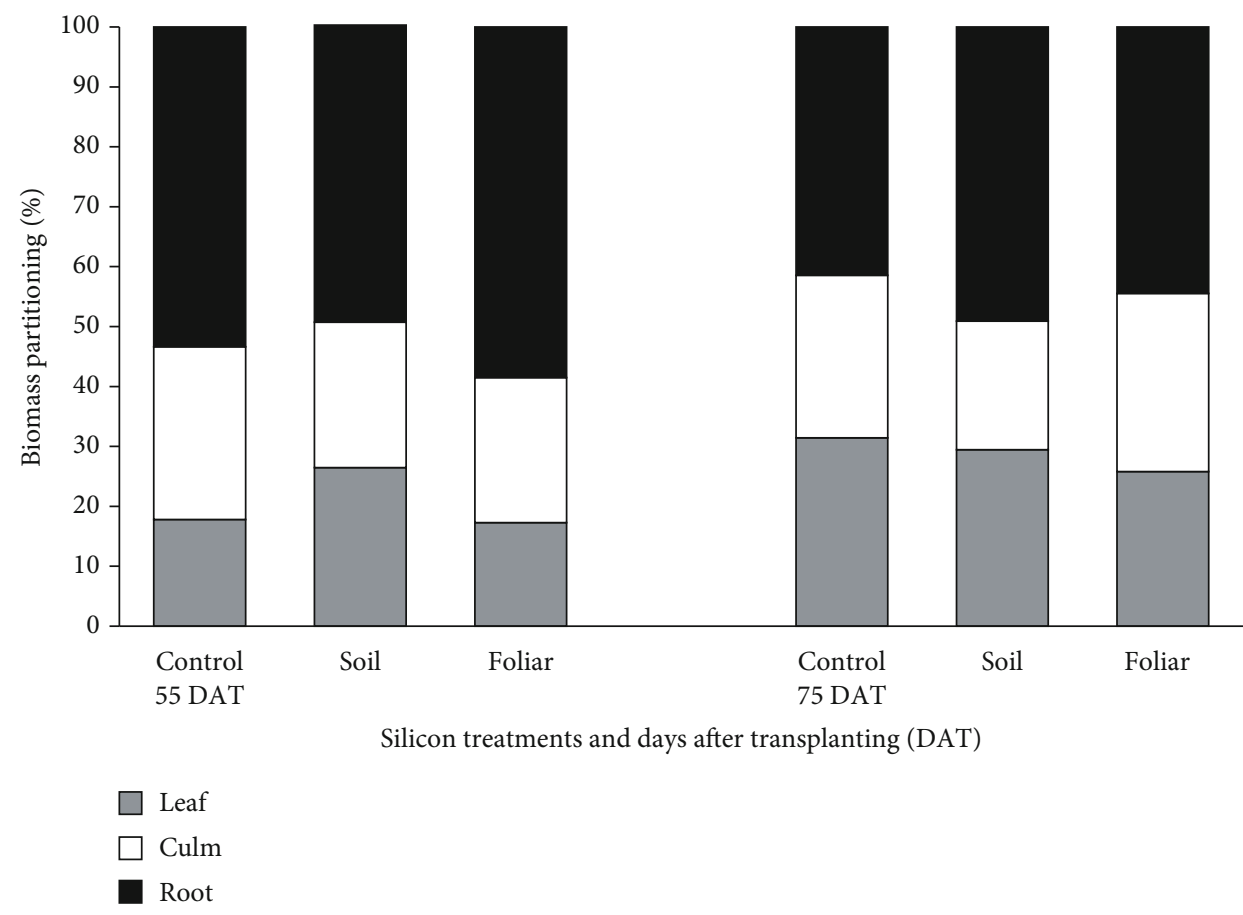

FIGURE 1: Whole plant percentage dry matter partitioning from different Si method applications at 55 and 75 DAT in rice plants.

treatments. The results revealed a reduction in the internode length at 75 DAT in both methods of Si treatments. Compared to the control, the reductions were by $14 \%$ in the topdressing and $9 \%$ in the foliar applied treatments.

3.2. Physiological Responses. The photosynthesis rate $(\mathrm{Pn})$ on different Si method applications at 55 and 75 DAT in rice plants is presented in Table 3. The photosynthesis rates of plants treated with the Si topdressed and Si foliar spray methods were significantly different at $55 \mathrm{DAT}$, with the values of 11.3 and $11.0 \mu \mathrm{mol} \mathrm{CO} \mathrm{m}^{-2} \mathrm{~s}^{-1}$, respectively. Moreover, both $\mathrm{Si}$ treatments increased the Pn by 30 ( $\mathrm{Si}$ foliar applied methods) and 26\% (Si topdressed methods).

Stomatal conductance measurements shared similarities with the photosynthesis rate (as shown in Table 3). Plants treated with $\mathrm{Si}$ topdressing treatments were significantly different in stomatal conductance at 55 DAT, with a value of $183 \mathrm{mmol} \mathrm{H}_{2} \mathrm{O} \mathrm{m} \mathrm{m}^{-2} \mathrm{~s}^{-1}$, or by a $65 \%$ increase compared to other treatments.

The relative chlorophyll content of different $\mathrm{Si}$ method applications at 55 and 75 DAT in rice plants is shown in Table 3. Si foliar-treated plants increased in chlorophyll content, with the highest mean value of 32.52 SPAD unit at 55 DAT compared to the control. Likewise, the relative chlorophyll content showed no significant difference at 75 DAT.

3.3. Biomass Partitioning. Figure 1 and Table 4 illustrate the pattern of biomass partitioning in PadiU Putra rice plants with different Si method applications at 55 and 75 DAT. At 55 DAT, a statistical analysis revealed that Si foliar applied and Si topdressing treatments resulted in biomass partitioning to the leaves, culm, and roots being significantly different compared to the control (Table 4). Remarkably, Si foliar applied treatments were significantly different in biomass 
TABLE 4: Dry matter production on different Si method applications at 55 and 75 DAT in rice plants.

\begin{tabular}{|c|c|c|c|c|c|c|c|c|c|c|}
\hline \multirow{2}{*}{$\begin{array}{l}\text { Biomass partitioning } \\
\text { DAT }\end{array}$} & \multicolumn{2}{|c|}{ Leaf $\left(\mathrm{g} \mathrm{hill}^{-1}\right)$} & \multicolumn{2}{|c|}{ Culm $\left(\mathrm{g} \mathrm{hill}^{-1}\right)$} & \multicolumn{2}{|c|}{ Root $\left(\mathrm{g} \mathrm{hill}^{-1}\right)$} & \multicolumn{2}{|c|}{ Total $\left(\mathrm{g} \mathrm{hill}^{-1}\right)$} & \multicolumn{2}{|c|}{ Root: shoot ratio } \\
\hline & 55 & 75 & 55 & 75 & 55 & 75 & 55 & 75 & 55 & 75 \\
\hline Control & $2.9 \mathrm{~b}$ & $16.9 \mathrm{a}$ & $4.7 \mathrm{~b}$ & $14.6 \mathrm{~b}$ & $8.7 c$ & $22.3 \mathrm{~b}$ & $16.3 \mathrm{c}$ & $53.8 \mathrm{~b}$ & $0.49 c$ & $0.72 \mathrm{c}$ \\
\hline Topdressing & $6.4 \mathrm{a}$ & $14.4 \mathrm{~b}$ & $5.9 \mathrm{~b}$ & $10.5 c$ & $12.0 \mathrm{~b}$ & $24.0 \mathrm{~b}$ & $24.2 \mathrm{~b}$ & $48.9 \mathrm{~b}$ & $0.98 \mathrm{~b}$ & $0.97 \mathrm{a}$ \\
\hline Foliar spray & $7.5 \mathrm{a}$ & $16.3 \mathrm{a}$ & $10.5 \mathrm{a}$ & $18.8 \mathrm{a}$ & $25.4 \mathrm{a}$ & $28.1 \mathrm{a}$ & $43.4 \mathrm{a}$ & $63.2 \mathrm{a}$ & $1.41 \mathrm{a}$ & $0.80 \mathrm{~b}$ \\
\hline $\operatorname{LSD}_{(P=0.05)}$ & 0.57 & 2.12 & 1.88 & 1.99 & 0.69 & 3.77 & 1.37 & 0.69 & 3.33 & 2.12 \\
\hline $\mathrm{CV}$ & 7.98 & 8.62 & 5.67 & 7.65 & 7.64 & 6.03 & 10.09 & 7.46 & 5.64 & 3.49 \\
\hline
\end{tabular}

Mean values followed by the same letters within a column are not significantly different at $P \leq 0.05$ by the LSD test. DAT: days after transplanting; CV: coefficient of variation.

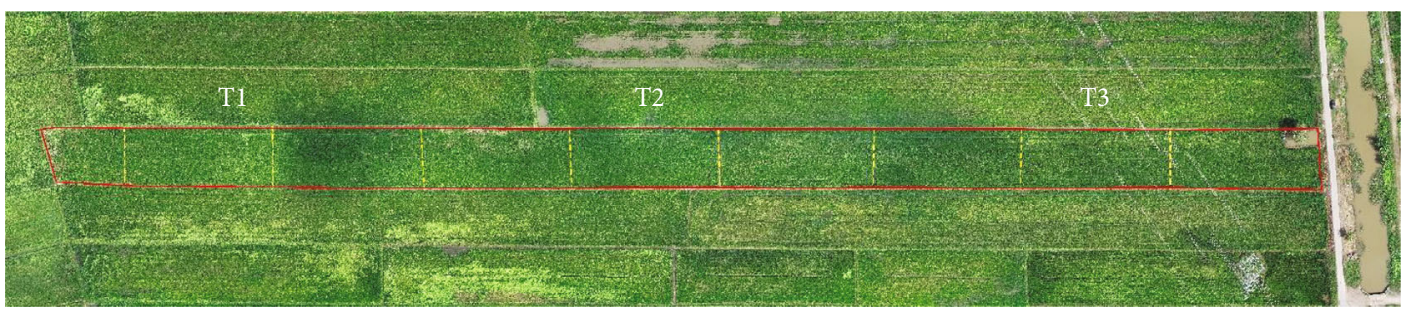

(a)

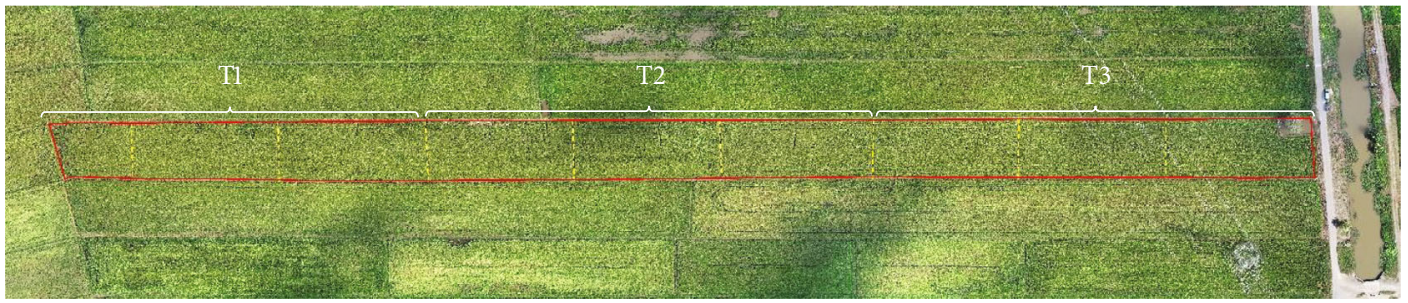

(b)
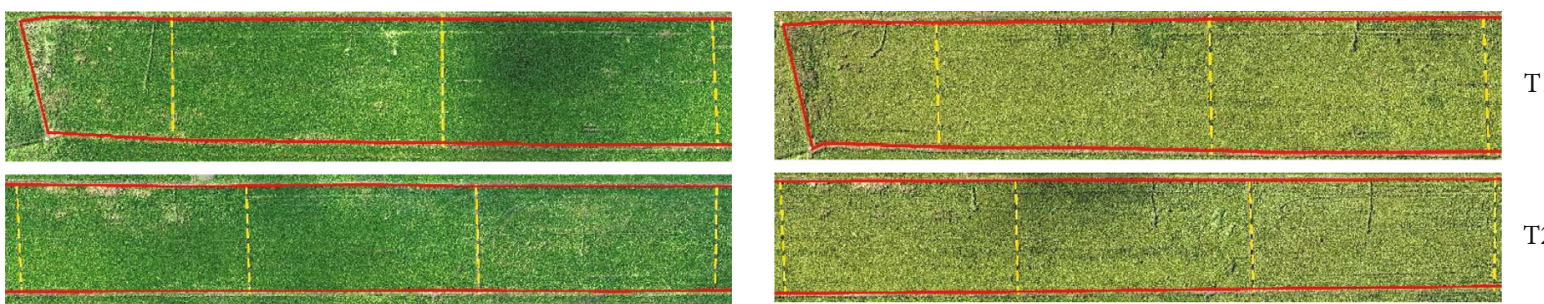

$\mathrm{T} 2$
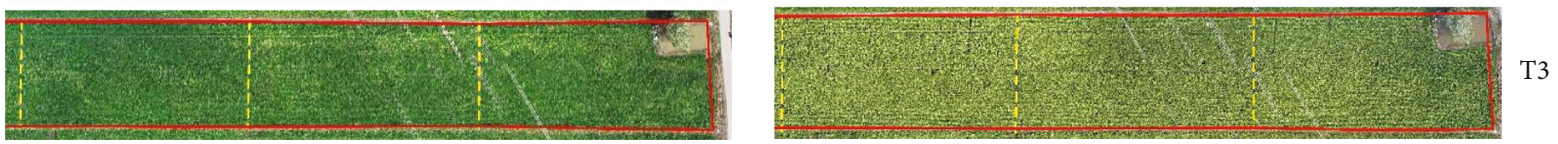

(c)

(d)

Figure 2: Boundary of the study area in this research at Tunjang, Jitra, Kedah, Malaysia at (a) 55 and (b) 75 DAT. Boundary of each of the treatment plots (T1: control/untreated plants; T2: Si topdressing plants; and T3: Si foliar applied plants) at (c) 55 and (d) 75 DAT.

partitioning to the leaves, culm, and roots, following samples at $75 \mathrm{DAT}$. As for the total biomass partitioning, plants treated with Si foliar spray showed the highest dry matter production per hill at 55 and 75 DAT, where 43.4 and $63.2 \mathrm{~g} \mathrm{hill}^{-1}$ were observed. Similar to the results from the root to shoot ratio, the application of $\mathrm{Si}$ foliar applied treatments showed the highest value compared to other treatments, with 1.41. Meanwhile, the application of Si topdressing treatments had the highest root to shoot ratio at 75 DAT, with 0.97 .
In whole plant percentage dry matter partitioning, the highest dry matter partitioning occurred with the leaves, by $27 \%$, in the Si topdressing; culm, by $29 \%$ in the control; and roots, by $59 \%$ in the Si foliar applied treatments. These were observed at 55 DAT (Figure 1). In contrast, biomass was partitioned to the leaves by $31 \%$ in the control; culm by $29 \%$ in the Si foliar applied, and roots by $49 \%$ in the Si topdressing treatments. These were observed at 75 DAT. The leaves and roots were most affected by the partitioning changes under both Si applied treatments, respectively, compared to other 


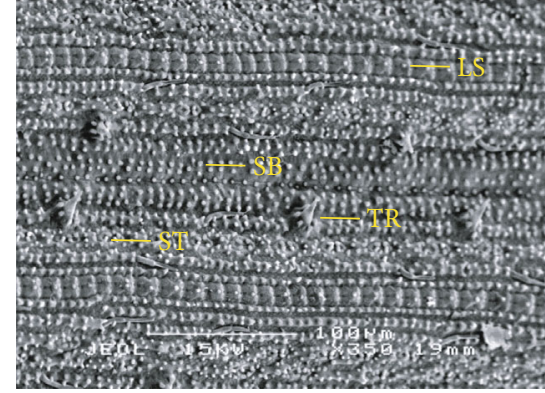

(a)

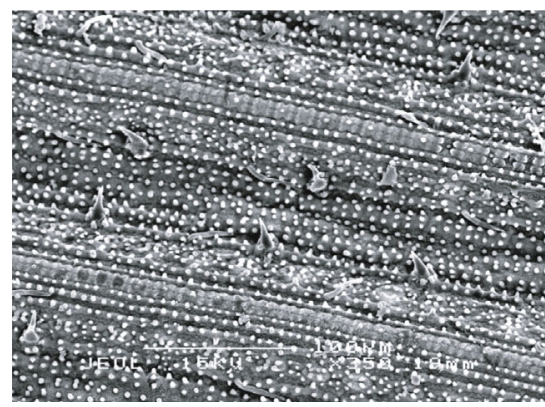

(c)

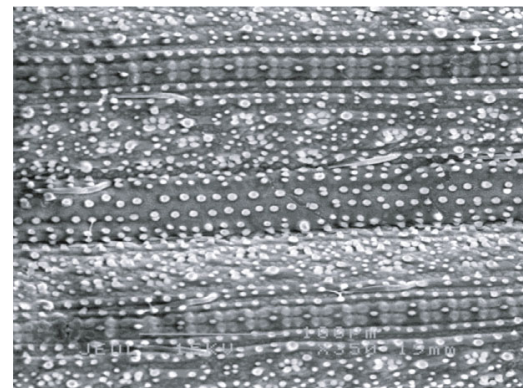

(e)

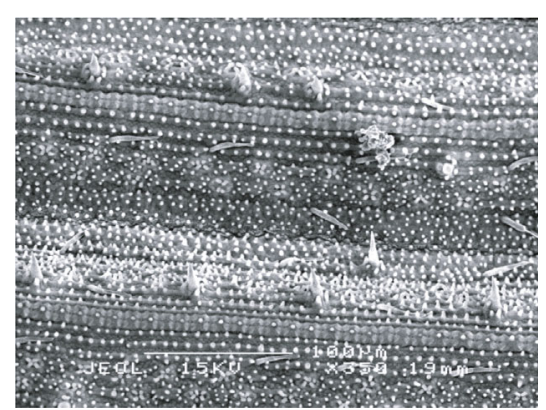

(b)

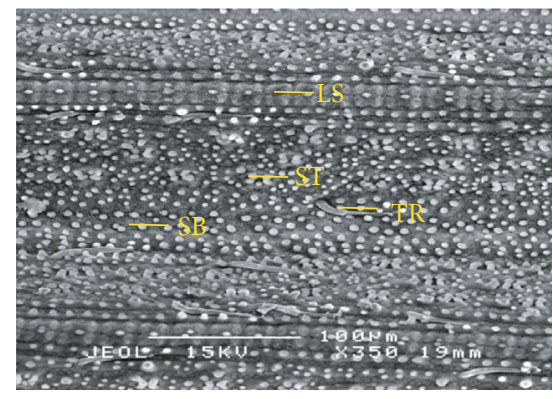

(d)

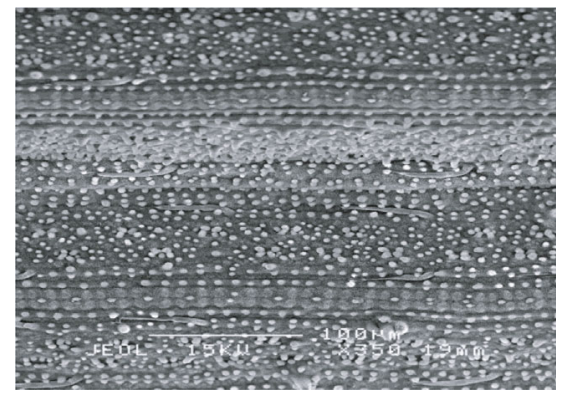

(f)

FiguRE 3: SEM image of the epidermal region of a rice plant leaf. The white granular areas of Si were detected on the abaxial leaf surfaces (a-c) at 55 DAT and (d-f) at 75 DAT at magnification 350x. LS: ladder-like structures; SB: silica bodies; TR: trichomes; ST: stomas.

parts of the plant, especially at 55 DAT. In addition, at 75 DAT, Si foliar applied and Si topdressing treatments affected greater culm and root development of the rice plants compared to the control. According to the biomass partitioning, Si topdressing treatments improved dry matter partitioning into the leaves by $9 \%$ and $8 \%$ at 55 and $75 \mathrm{DAT}$, respectively, compared to the control. A similar pattern was observed in the $\mathrm{Si}$ foliar applied treatments, where $5 \%$ and $3 \%$ of dry matter partitioning into roots and culm, respectively, were enhanced, compared to the control treatments.

3.4. Crop Growth Map Using Unmanned Aerial Vehicle (UAV) and RGB Digital Camera. Figure 2 shows the boundary of the study area in this research during the main planting season, made using a multirotor UAV at an altitude of 80 metres from the ground to monitor rice crop management and yield prediction, at 55 and 75 DAT. The red, green, and blue (RGB) image illustrates that the whole of the study area was about 1.42 ha. Based on Figures 2(a)-2(d), the rice plants showed uniformly as a dark green colour in the plot, indicating better plant growth performance at $55 \mathrm{DAT}$, espe- cially from foliar applied treatments. Similar findings were observed at 75 DAT, where the rice plants consistently demonstrated a light yellowish colour in all plots. However, in the control treatment, darker greenish and yellow colours were spotted around the plot.

\subsection{Scanning Electron Microscopy (SEM) Observations}

3.5.1. SEM Investigation of Rice Leaves at 55 and 75 DAT. In SEM observations, various structures were identified in the rice leaves, including silica bodies, ladder-like structures or dumbbell-shaped trichomes (fine outgrowths or appendages on plants), and stomas (as shown in Figure 3). Essentially, identical structures were found on all treatments of the leaves, regardless of the sampling times.

Si foliar applied treatments were significantly different in terms of the number of trichomes per field of view at 75 DAT (as shown in Table 5). Trichome distribution in Si foliar applied treatments was the highest by $29 \%$, compared to other treatments. Similar findings were noted with the length of the ladder-like structures. The Si topdressing and Si foliar 
TABLE 5: Number of trichomes, ladder-like structures, and length of ladder-like structures of rice leaves with different Si method applications at 55 and 75 DAT.

\begin{tabular}{|c|c|c|c|c|c|c|}
\hline \multirow[t]{2}{*}{ Treatment } & \multicolumn{2}{|c|}{$\begin{array}{l}\text { Number of trichomes per } \\
\text { field of view (FOV) }\end{array}$} & \multicolumn{2}{|c|}{$\begin{array}{c}\text { Number of ladder-like } \\
\text { structure per field of } \\
\text { view (FOV) } \\
\text { DAT }\end{array}$} & \multicolumn{2}{|c|}{$\begin{array}{l}\text { Length of ladder-like } \\
\text { structure }(\mu \mathrm{m})\end{array}$} \\
\hline & 55 & 75 & 55 & 75 & 55 & 75 \\
\hline Control & $6 a$ & $5 b$ & $26 a$ & $15 \mathrm{a}$ & $5.75 \mathrm{a}$ & $8.67 \mathrm{~b}$ \\
\hline Topdressing & $5 a$ & $4 \mathrm{~b}$ & $26 a$ & $16 \mathrm{a}$ & $4.09 \mathrm{~b}$ & $9.95 \mathrm{a}$ \\
\hline Foliar spray & $8 a$ & $7 \mathrm{a}$ & $24 \mathrm{a}$ & $14 \mathrm{a}$ & $3.49 \mathrm{~b}$ & $9.97 \mathrm{a}$ \\
\hline $\operatorname{LSD}_{(P=0.05)}$ & 4.16 & 1.15 & 3.83 & 1.73 & 1.58 & 2.87 \\
\hline $\mathrm{CV}$ & 2.45 & 12.50 & 2.79 & 6.39 & 4.25 & 7.39 \\
\hline
\end{tabular}

Mean values followed by the same letters within a column are not significantly different at $P \leq 0.05$ by the LSD test. DAT: days after transplanting; CV: coefficient of variation. Number of trichomes and ladder-like structures (FOV) were counted at magnification 350x.

TABLE 6: Characteristics of rice leaves in terms of number of silica bodies and distances between silica bodies from different Si method applications at 55 and 75 DAT in rice plants.

\begin{tabular}{|c|c|c|c|c|c|}
\hline \multirow{2}{*}{ Treatment } & \multicolumn{2}{|c|}{$\begin{array}{c}\text { Number of silica bodies per field of } \\
\text { view (FOV) }\end{array}$} & \multirow{2}{*}{ DAT } & \multicolumn{2}{|c|}{$\begin{array}{l}\text { Distance between adjacent silica } \\
\text { bodies }(\mu \mathrm{m})\end{array}$} \\
\hline & 55 & 75 & & 55 & 75 \\
\hline Control & $211 b$ & $211 b$ & & $4.49 \mathrm{~b}$ & $5.22 \mathrm{~b}$ \\
\hline Topdressing & $248 \mathrm{a}$ & $262 \mathrm{a}$ & & $5.40 \mathrm{a}$ & $6.37 \mathrm{a}$ \\
\hline Foliar spray & $211 b$ & $216 b$ & & $4.36 \mathrm{~b}$ & $6.32 \mathrm{a}$ \\
\hline $\operatorname{LSD}_{(P=0.05)}$ & 12.93 & 11.96 & & 1.12 & 1.77 \\
\hline $\mathrm{CV}$ & 7.89 & 2.90 & & 6,40 & 1.97 \\
\hline
\end{tabular}

Mean values followed by the same letters within a column are not significantly different at $P \leq 0.05$ by the LSD test. DAT: days after transplanting; CV: coefficient of variation. Number of silica bodies (FOV) was counted at magnification 1000x.

TABle 7: Stomatal characteristics of rice leaves with different Si method applications at 55 and 75 DAT.

\begin{tabular}{|c|c|c|c|c|c|c|}
\hline \multirow{2}{*}{ Treatment } & \multicolumn{2}{|c|}{$\begin{array}{l}\text { Number of stomata per } \\
\text { field of view (FOV) }\end{array}$} & \multicolumn{2}{|c|}{ Stomatal diameter $(\mu \mathrm{m})$} & \multicolumn{2}{|c|}{ Stomatal width $(\mu \mathrm{m})$} \\
\hline & 55 & 75 & 55 & 75 & 55 & 75 \\
\hline Control & $4 \mathrm{~b}$ & $46 \mathrm{~b}$ & $12.00 \mathrm{a}$ & $8.02 b$ & $2.06 \mathrm{~b}$ & $4.06 \mathrm{~b}$ \\
\hline Topdressing & $5 b$ & $57 \mathrm{a}$ & $12.18 \mathrm{a}$ & $17.40 \mathrm{a}$ & $2.36 \mathrm{a}$ & $4.08 \mathrm{~b}$ \\
\hline Foliar spray & $8 \mathrm{a}$ & $47 \mathrm{~b}$ & $10.80 \mathrm{a}$ & $17.40 \mathrm{a}$ & $2.48 \mathrm{a}$ & $5.63 \mathrm{a}$ \\
\hline $\operatorname{LSD}_{(P=0.05)}$ & 2.11 & 11.96 & 1.81 & 6.06 & 1.79 & 1.53 \\
\hline $\mathrm{CV}$ & 8.63 & 2.40 & 5.50 & 8.32 & 5.19 & 9.10 \\
\hline
\end{tabular}

Mean values followed by the same letters within a column are not significantly different at $P \leq 0.05$ by the LSD test. DAT: days after transplanting; CV: coefficient of variation. Number of stomata (FOV) was counted at magnification 1000x.

applied treatments were significantly different to the control at 75 DAT, with 9.95 and $9.97 \mu \mathrm{m}$, respectively. The leaf samples of plants treated with both Si treatments showed a $13 \%$ extralength ladder-like structure in a row of silica cells and small silica bodies all around the sample.

The adaxial surfaces of the plants with Si topdressing treatments showed the highest number of silica bodies per view with $248(18 \%)$ and $262(24 \%)$, respectively, at both sampling times (Table 6). However, Si foliar applied treatments and control treatments were slightly different in terms of the number of silica bodies per view, observed at 55 and 75 DAT. In another parameter, the distance between the adjacent silica bodies was significantly different in $\mathrm{Si}$ topdressing treatments $(5.40 \mu \mathrm{m})$ at $55 \mathrm{DAT}$, compared to other treatments. Interestingly, plants applied with $\mathrm{Si}$ topdressing and Si foliar spray at 75 DAT showed significantly higher distances between adjacent silica bodies than the control; the former two treatments showed 6.37 and $6.32 \mu \mathrm{m}$, respectively.

Table 7 shows the stomatal characteristics of rice leaves with different Si method applications at 55 and 75 DAT in rice plants. The highest number of stomata per field of view was obtained when Si was applied as foliar spray and for Si topdressed plants at 55 and 75 DAT, respectively. Si foliar applied and Si topdressing treatments showed an increased number of stomata per view, by 50 and $19 \%$ at 55 and 75 


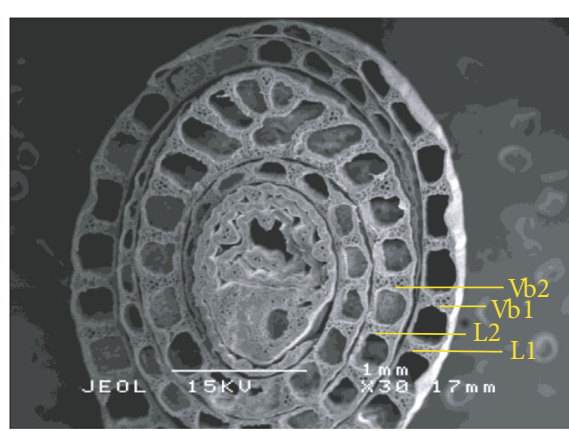

(a)

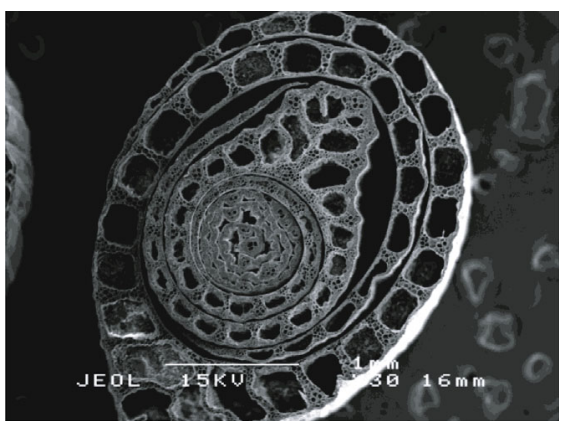

(c)

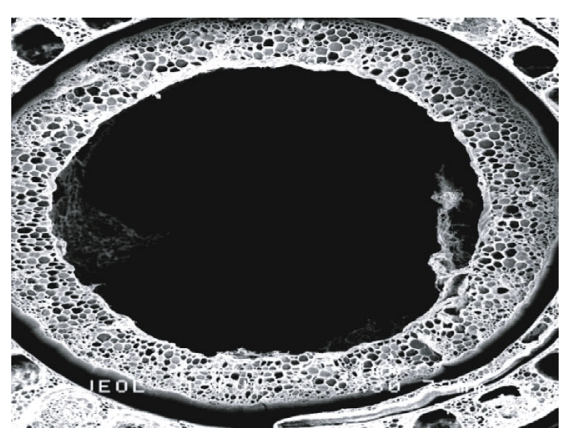

(e)

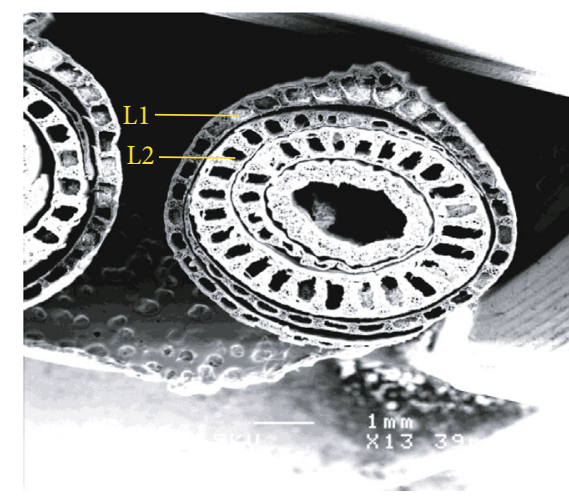

(g)

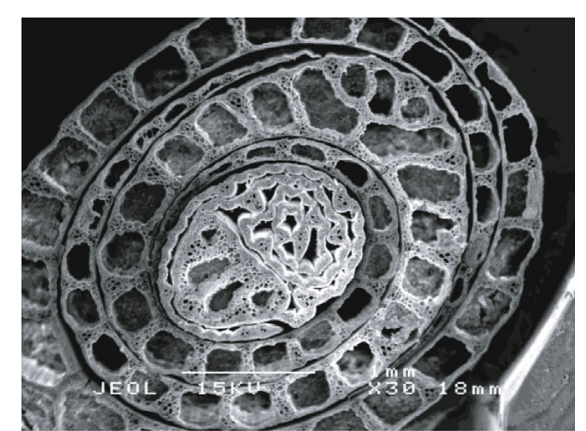

(b)

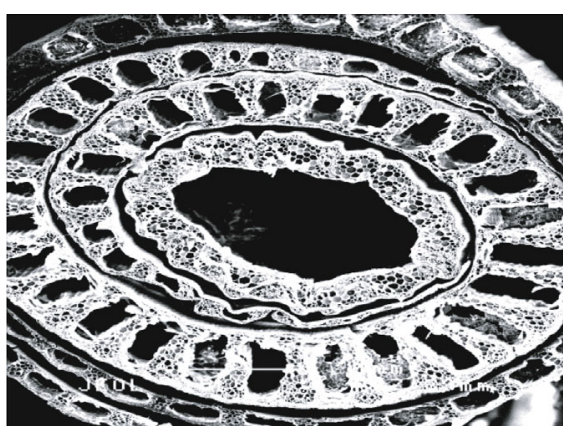

(d)

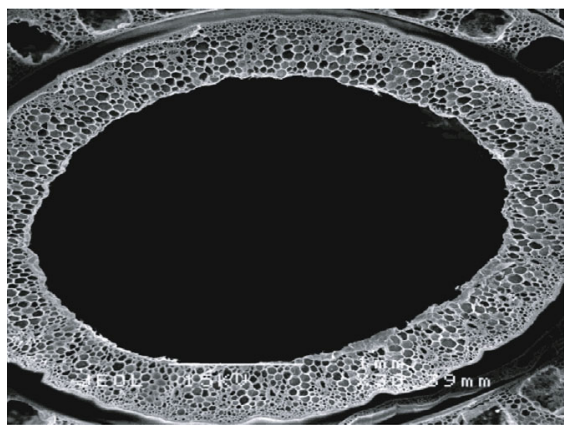

(f)

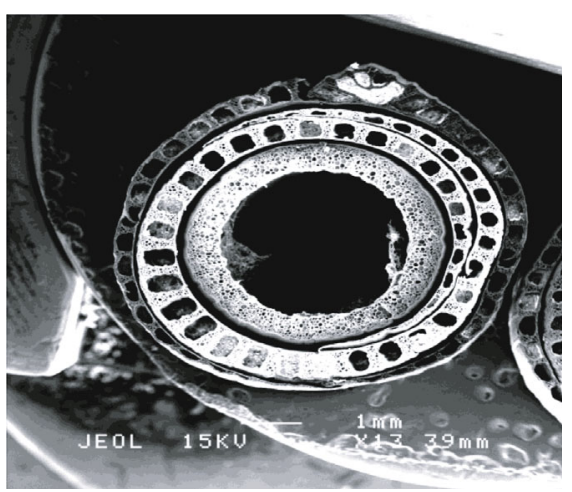

(h)

Figure 4: Continued. 


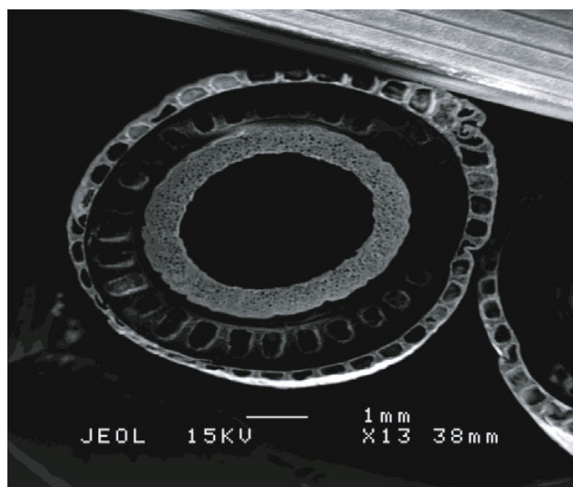

(i)

FIGURE 4: SEM image of the epidermal regions of rice plant culm sheaths. (a-c) at 55 DAT, $(d-f)$ at 75 DAT at magnification $30 x$, and $(g$, h) at 75 DAT at magnification 13x. vb: vascular bundles.

TABLE 8: The diameter and width of the culm with different Si method applications at 55 and 75 DAT in rice plants.

\begin{tabular}{|c|c|c|c|c|c|c|c|c|}
\hline \multirow{2}{*}{ Treatment } & \multicolumn{2}{|c|}{ Culm diameter (mm) } & \multicolumn{2}{|c|}{ Culm width (mm) } & \multicolumn{2}{|c|}{$\begin{array}{l}\text { Culm middle } \\
\text { diameter }(\mathrm{mm})\end{array}$} & \multicolumn{2}{|c|}{$\begin{array}{l}\text { Culm middle width } \\
(\mathrm{mm})\end{array}$} \\
\hline & 55 & 75 & 55 & 75 & 55 & 75 & 55 & 75 \\
\hline Control & $3130 \mathrm{~b}$ & $7927 a$ & $2639 b$ & $4888 a$ & $2254 a$ & $3678 a$ & $1782 a$ & $1942 b$ \\
\hline Topdressing & $4171 \mathrm{a}$ & $5684 b$ & $2888 \mathrm{a}$ & $3981 b$ & $2147 \mathrm{a}$ & $2782 b$ & $1571 \mathrm{a}$ & $2543 a$ \\
\hline Foliar spray & $3307 \mathrm{~b}$ & $7310 \mathrm{a}$ & $2146 c$ & $4218 \mathrm{a}$ & $1653 b$ & $3216 a$ & $1261 \mathrm{a}$ & $767 c$ \\
\hline $\operatorname{LSD}_{(P=0.05)}$ & 5.64 & 7.40 & 4.99 & 5.70 & 3.14 & 6.80 & 13.21 & 12.00 \\
\hline $\mathrm{CV}$ & 6.50 & 9.19 & 6.82 & 5.67 & 8.37 & 8.90 & 6.92 & 5.62 \\
\hline
\end{tabular}

Mean values followed by the same letters within a column are not significantly different at $P \leq 0.05$ by the LSD test. DAT: days after transplanting; CV: coefficient of variation.

DAT, respectively. As for the method of application, the stomata diameters of Si foliar applied and Si topdressing were significantly higher than the control at $75 \mathrm{DAT}$, at $17.40 \mu \mathrm{m}$. Similar results were found with stomatal width, where $\mathrm{Si}$ foliar applied $(2.48 \mu \mathrm{m})$ and Si topdressing $(2.36 \mu \mathrm{m})$ were significantly different than the control at 55 DAT. Remarkably, both $\mathrm{Si}$ treatments improved stomata diameter by $117 \%$ and stomata width by $39 \%$ in Si foliar applied treatments at 75 DAT. Si foliar applied at 75 DAT had the highest stomatal width, followed by Si topdressing treatments and the control, though they were insignificantly different. Stomatal width in rice plant leaves had a markedly increased photosynthesis rate in this study using the Si treatments. There was a positive linear relationship between stomatal width and the photosynthesis rate for all treatments, with correlation $y=0.2948 x-0.4951$. The significant coefficients of 0.85 in the relationship showed that the highest stomatal width was obtained with a $5.63 \mu \mathrm{m}$ photosynthesis rate in $\mathrm{Si}$ foliar applied treatments at 75 DAT.

3.5.2. SEM Investigation in Rice Culm at 55 and 75 DAT. To further identify the factors responsible for the effects of different Si method applications on the rice plant strength, the anatomical structure of the plants was analysed for each of the treatments with $\times 30$ and $\times 200$ magnification, as shown in Figure 4. In the transverse sections, the characteristics of layer thickness and vascular bundles were observed.

The diameter of the culm was significantly different in both Si method applications (Table 8). The diameter of the culm of the topdressing treatments $(4171 \mathrm{~mm})$ was significantly higher than the Si foliar applied treatments and control plants at 55 DAT. Interestingly, similar findings relating to the width and middle width of the culm were obtained in Si topdressing treatments at 55 DAT, with 2888 and $2147 \mathrm{~mm}$, respectively. The diameter and width of the culm were higher when Si was applied as topdressing; they increased by $33 \%$ and $9 \%$, respectively, compared to the Si foliar applied treatments and the control. Like the middle with of the culm, Si topdressing treatments showed the broadest rice culm at $31 \%$.

The culm wall thickness of the first layer was significantly different depending on the method of $\mathrm{Si}$ application (Table 9). Si applied as topdressing treatments had the highest culm wall thickness of the first layer, followed by the Si foliar treatments and the control at 55 DAT. Meanwhile, Si foliar applied treatments were significantly higher than other treatments at 75 DAT. Likewise, the culm wall thickness of the second layer showed no significance at 55 and 75 DAT. In the Si topdressing and Si foliar applied treatments, the culm wall thickness of the first layer was the highest, with 9 and $24 \%$ at 55 and 75 DAT, respectively. The culm wall 
TABLE 9: Culm wall thickness of rice plants with different Si method applications at 55 and 75 DAT.

\begin{tabular}{|c|c|c|c|c|c|c|}
\hline \multirow{2}{*}{ Treatment } & \multicolumn{2}{|c|}{$\begin{array}{c}\text { Culm wall thickness of the } \\
1^{\text {st }} \text { layer }(\mu \mathrm{m})\end{array}$} & \multicolumn{2}{|c|}{$\begin{array}{c}\text { Culm wall thickness of } \\
\text { the } 2^{\text {nd }} \text { layer }(\mu \mathrm{m}) \\
\text { DAT }\end{array}$} & \multicolumn{2}{|c|}{$\begin{array}{c}\text { Culm wall thickness of the } \\
3^{\text {rd }} \text { layer }(\mu \mathrm{m})\end{array}$} \\
\hline & 55 & 75 & 55 & 75 & 55 & 75 \\
\hline Control & $308 b$ & $266 c$ & $322 a$ & $305 a$ & $312 b$ & $339 a$ \\
\hline Topdressing & $337 \mathrm{a}$ & $295 b$ & $338 \mathrm{a}$ & $293 a$ & $295 b$ & $320 \mathrm{a}$ \\
\hline Foliar spray & $294 b$ & $330 a$ & $324 a$ & $286 a$ & $387 a$ & $344 \mathrm{a}$ \\
\hline $\operatorname{LSD}_{(P=0.05)}$ & 10.7 & 18.01 & 10.5 & 14.87 & 12.73 & 15.04 \\
\hline $\mathrm{CV}$ & 2.45 & 6.30 & 7.78 & 3.45 & 7.50 & 3.98 \\
\hline
\end{tabular}

Mean values followed by the same letters within a column are not significantly different at $P \leq 0.05$ by the LSD test. DAT: days after transplanting; CV: coefficient of variation.

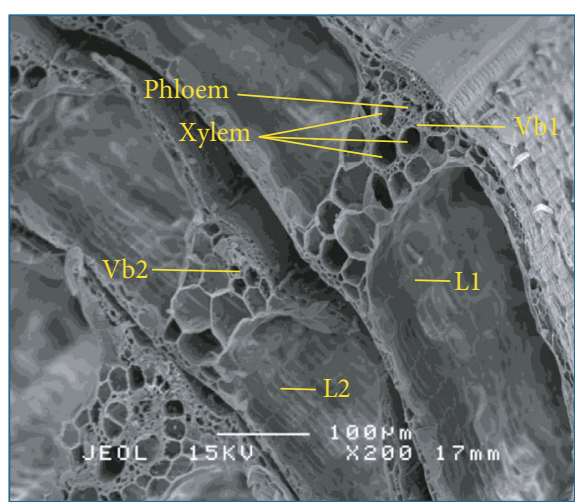

(a)

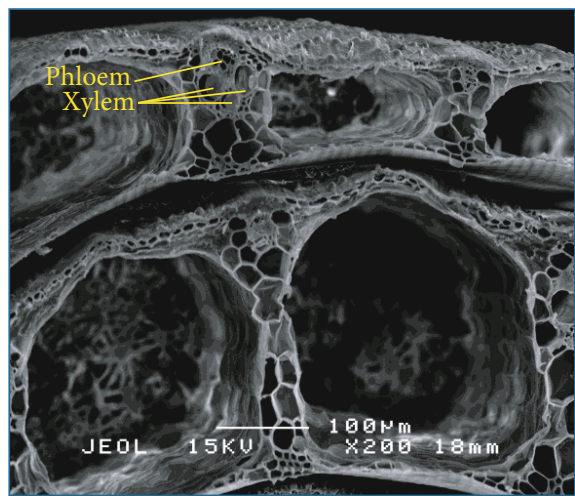

(c)

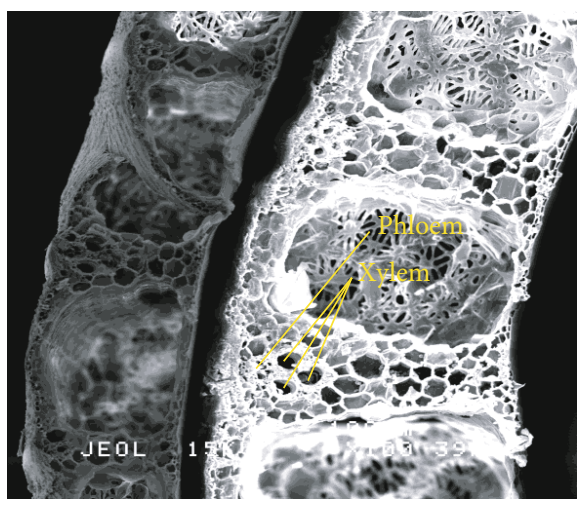

(e)

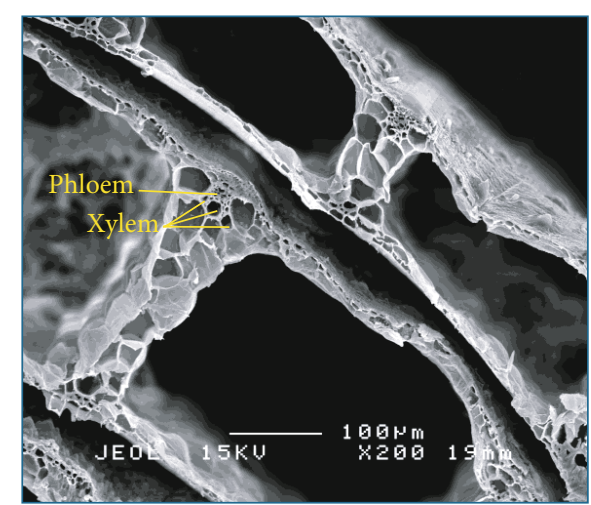

(b)

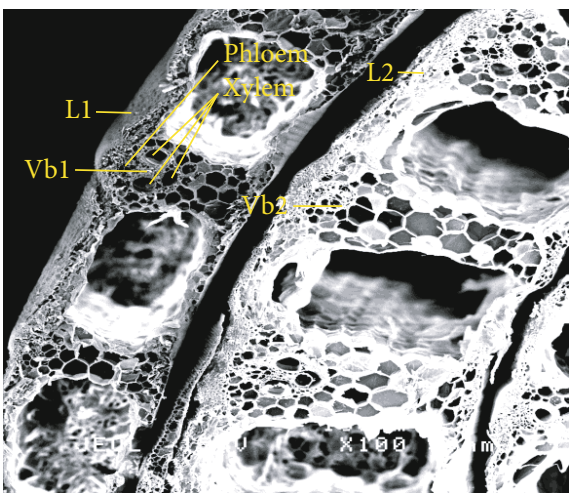

(d)

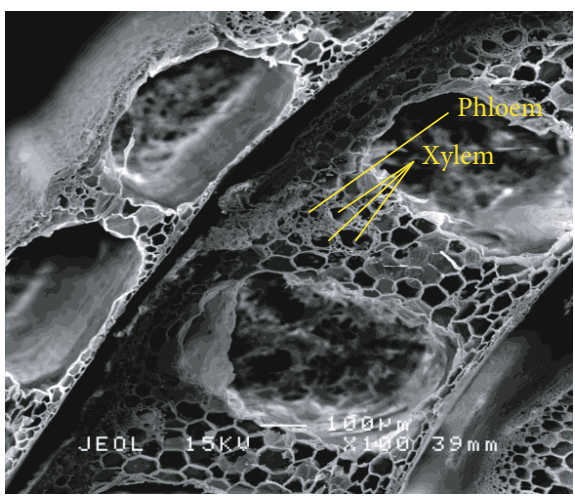

(f)

FIGURE 5: SEM image of the epidermal regions of rice plants. (a-c) At 55 DAT and (d-f) at 75 DAT at magnification 200x. L1: first layer; L2: second layer; $\mathrm{Vb} 1$ : vascular bundle at first layer; $\mathrm{Vb} 2$ : vascular bundle at second layer. 
TABLE 10: Vascular bundle characteristics of rice culm with different Si method applications at 55 and 75 DAT.

\begin{tabular}{|c|c|c|c|c|c|c|c|c|}
\hline \multirow[t]{2}{*}{ Treatment } & \multicolumn{2}{|c|}{$\begin{array}{l}\text { Outer layer diameter } \\
\text { of vascular bundles } \\
(\mu \mathrm{m})\end{array}$} & \multicolumn{2}{|c|}{$\begin{array}{l}\text { Outer layer width of } \\
\text { vascular bundles } \\
(\mu \mathrm{m})\end{array}$} & \multicolumn{2}{|c|}{$\begin{array}{l}\text { Inner layer diameter } \\
\text { of vascular bundles } \\
\qquad(\mu \mathrm{m})\end{array}$} & \multicolumn{2}{|c|}{$\begin{array}{c}\text { Inner layer width of } \\
\text { vascular bundles }(\mu \mathrm{m})\end{array}$} \\
\hline & 55 & 75 & 55 & 75 & 55 & 75 & 55 & 75 \\
\hline Control & $79.8 \mathrm{a}$ & $102.0 \mathrm{~b}$ & $58.8 \mathrm{a}$ & $47.7 \mathrm{c}$ & $59.5 a$ & $113.6 \mathrm{~b}$ & $48.8 \mathrm{a}$ & $121.0 \mathrm{a}$ \\
\hline Topdressing & $53.8 \mathrm{~b}$ & $96.9 b$ & $26.7 \mathrm{~b}$ & $102.0 \mathrm{~b}$ & $77.8 \mathrm{a}$ & $107.1 \mathrm{~b}$ & $49.4 \mathrm{a}$ & $100.2 b$ \\
\hline Foliar spray & $60.4 \mathrm{~b}$ & $161.5 \mathrm{a}$ & $27.8 \mathrm{~b}$ & $134.0 \mathrm{a}$ & $70.9 a$ & $204.0 \mathrm{a}$ & $40.3 \mathrm{a}$ & $117.0 \mathrm{ab}$ \\
\hline $\operatorname{LSD}_{(P=0.05)}$ & 17.88 & 25.95 & 18.98 & 4.61 & 19.48 & 25.53 & 32.28 & 17.16 \\
\hline $\mathrm{CV}$ & 7.95 & 9.55 & 6.98 & 9.76 & 7.80 & 5.76 & 8.80 & 7.91 \\
\hline
\end{tabular}

Mean values followed by the same letters within a column are not significantly different at $P \leq 0.05$ by the LSD test. DAT: days after transplanting; CV: coefficient of variation.

TABLE 11: Yield components of rice plants at 120 DAT with different Si method applications at 55 and 75 DAT.

\begin{tabular}{|c|c|c|c|c|c|}
\hline Treatment & Panicle length $(\mathrm{cm})$ & Spikelets per panicle & Filled grain (\%) & 1,000-grain weight $(\mathrm{g})$ & Yield $\left(\right.$ tha $\left.^{-1}\right)$ \\
\hline Control & $24.77 b$ & $175 b$ & $89.53 b$ & $26.03 b$ & $4.44 \mathrm{c}$ \\
\hline Topdressing & $26.53 a$ & $175 b$ & $91.87 \mathrm{~b}$ & $28.13 a$ & $6.15 b$ \\
\hline Foliar spray & $26.67 \mathrm{a}$ & $200 \mathrm{a}$ & $95.20 \mathrm{a}$ & $26.33 b$ & $6.80 \mathrm{a}$ \\
\hline $\operatorname{LSD}_{(P=0.05)}$ & 3.33 & 5.88 & 8.52 & 2.12 & 6.84 \\
\hline $\mathrm{CV}$ & 5.64 & 8.63 & 4.08 & 3.49 & 4.21 \\
\hline
\end{tabular}

Mean values followed by the same letters within a column are not significantly different at $P \leq 0.05$ by the LSD test. CV: coefficient of variation.

thickness of the third layer was significantly different for the Si foliar applied treatments, with $387 \mu \mathrm{m}$ at 55 DAT (24\%). The equation correlation between the culm wall thickness and the height of the plant was $y=-1.9362 x+461.79$ with $R^{2}=0.5193$. There was a negative linear relationship between them. The negative correlation indicated that the thickness of the culm increased, while the height of the plant decreased.

The images and results showed the presence of vascular bundles in the culm crosssections of rice plants in the outer and inner layers with 200x of magnification, regardless of treatment, are shown in Figure 5 and Table 10. However, there were differences in terms of the diameter and width of vascular bundles on both layers. In the control plants, the diameter and width of vascular bundles on the outer layers were widened more at early data collection (55 DAT) compared to other treatments. This was in contrast to $\mathrm{Si}$ foliar applied treatments, which showed significant differences in terms of diameter and width of the outer layer of vascular bundles and the inner layer of the diameter of vascular bundles with 161.5 (58\%), 134.0 (181\%), and 204.0 (80\%) $\mu \mathrm{m}$ at 75 DAT, respectively.

3.6. Yield Component at 120 DAT. The panicle length, number of grains per panicle, and percentage of filled grain were significantly different between treatments at 120 DAT (as shown in Table 11). Following that, Si foliar applied and $\mathrm{Si}$ topdressing treatments had the highest panicle length, with 26.67 and $26.53 \mathrm{~cm}$, respectively. Meanwhile, the number of grains per panicle was increased in Si foliar applied treatments by $14 \%$ compared to the control. Similar results were obtained with the grain filling percentage in Si foliar applied treatments, where an increase of $95.2 \%$ was obtained. On the
TABLE 12: Effects of different Si method applications on benefit-cost ratio (BCR) and net present value (NPV) in rice plants at 120 DAT.

\begin{tabular}{lcc}
\hline Treatment & Benefit-cost ratio & Net present value $\left(\mathrm{RM} \mathrm{ha}^{-1}\right)$ \\
\hline Control & $1.09 \mathrm{c}$ & $558.04 \mathrm{c}$ \\
Topdressing & $1.49 \mathrm{~b}$ & $2749.95 \mathrm{~b}$ \\
Foliar spray & $1.63 \mathrm{a}$ & $3583.13 \mathrm{a}$ \\
LSD $_{(P=0.05)}$ & 1.88 & 1.55 \\
$\mathrm{CV}$ & 5.67 & 2.45 \\
\hline
\end{tabular}

Mean values followed by the same letters within a column are not significantly different at $P \leq 0.05$ by the LSD test. CV: coefficient of variation.

other hand, Si topdressing treatments improved by $8 \%$ in terms of thousand-grain weight compared to other treatments. Interestingly, the yield production of rice significantly increased in Si foliar applied, followed by the Si topdressing treatments, by 53 and 39\%, respectively, compared to the control. A relatively higher rice yield was associated with the Si foliar applied and Si topdressing treatments, with 6.8 and $6.15 \mathrm{tha}^{-1}$, compared to the national Malaysia average yield of $4.8 \mathrm{tha}^{-1}$.

3.7. Economic Viability of Adopting Si Topdressing and Si Foliar Applied Treatments in Rice Plants. Table 12 summarises the benefit-cost ratio (BCR) and net present value (NPV) of the different Si treatments used in rice cultivation with the Padiu Putra rice variety (Figures 6-8). The Si foliar applied and Si topdressing treatments produced higher yield and were more profitable during this planting season compared to the control. From an economic perspective (BCR), 


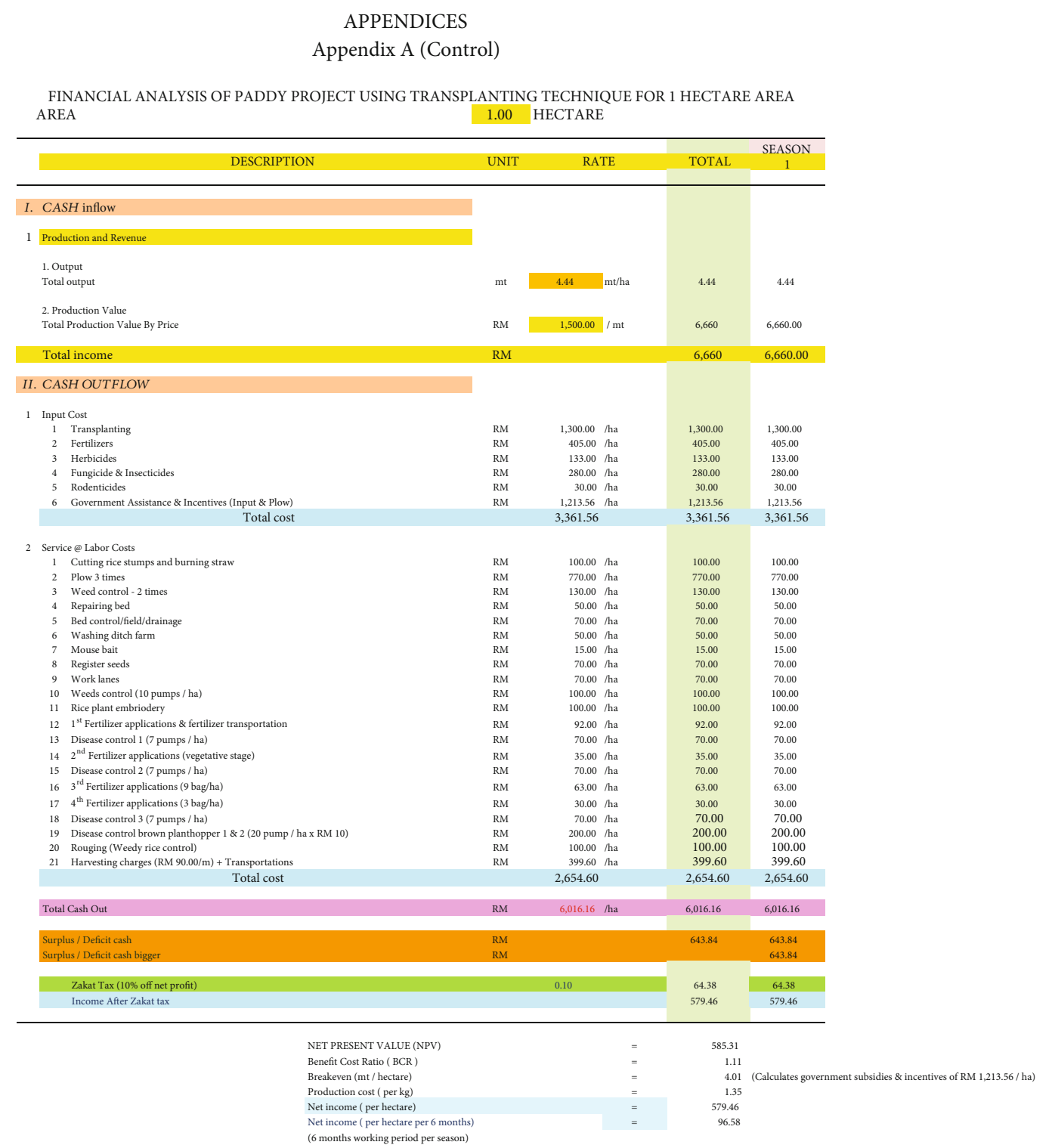

FIGURE 6: Financial analysis of paddy project using transplanting technique for one hectare of area (control).

for every RM 1 spent in adopting the Si foliar applied and Si topdressing treatments, RM 1.59 and RM 1.47 were gained in return, respectively. In terms of NPV, the Si foliar applied and $\mathrm{Si}$ topdressing treatments were more economically viable compared to the control, producing an additional income of RM 2843.27 ha $\mathrm{ha}^{-1}$ and RM $2101 \mathrm{ha}^{-1}$, respectively. The income generation of farmers improved by 486 and $359 \%$ with the $\mathrm{Si}$ foliar applied and Si topdressing treatments.

\section{Discussion}

Rice lodging is associated with height reduction, as stems weaken when supporting the weight of the grain, causing it to fall over. This is becoming a significant factor in rice production and often results in significant yield losses. Si application treatment is one of the approaches to fortify the leaf and culm sheaths and ultimately enhance rice yield. Broadcasting techniques, such as topdressing and foliar spray, are the common fertilisers used by the farmers, as they cost less but are very effective.

Reducing the plant height and internode length and the diameter of the internode are the first responsive events of plants to lodging and commonly regulated by Si amendments [34]. There were positive indications with Si application in terms of physiological measurement such as photosynthesis, chlorophyll content [12, 35], and biomass partitioning [36]. These physiological measurements were supported with images using the UAV and can be used for rice yield predictions $[30,37]$.

Si foliar applied treatments that are capable of altering physiological and anatomical structures are preferred, for they could fortify the leaf and culm sheaths and ultimately increase rice yield production. The greater improvement of biomass partitioning to the leaf and root in the early stages using Si topdressing and foliar applied was followed by the culm and root being affected at the reproductive stages by 
Appendix B (Si Topdressing)

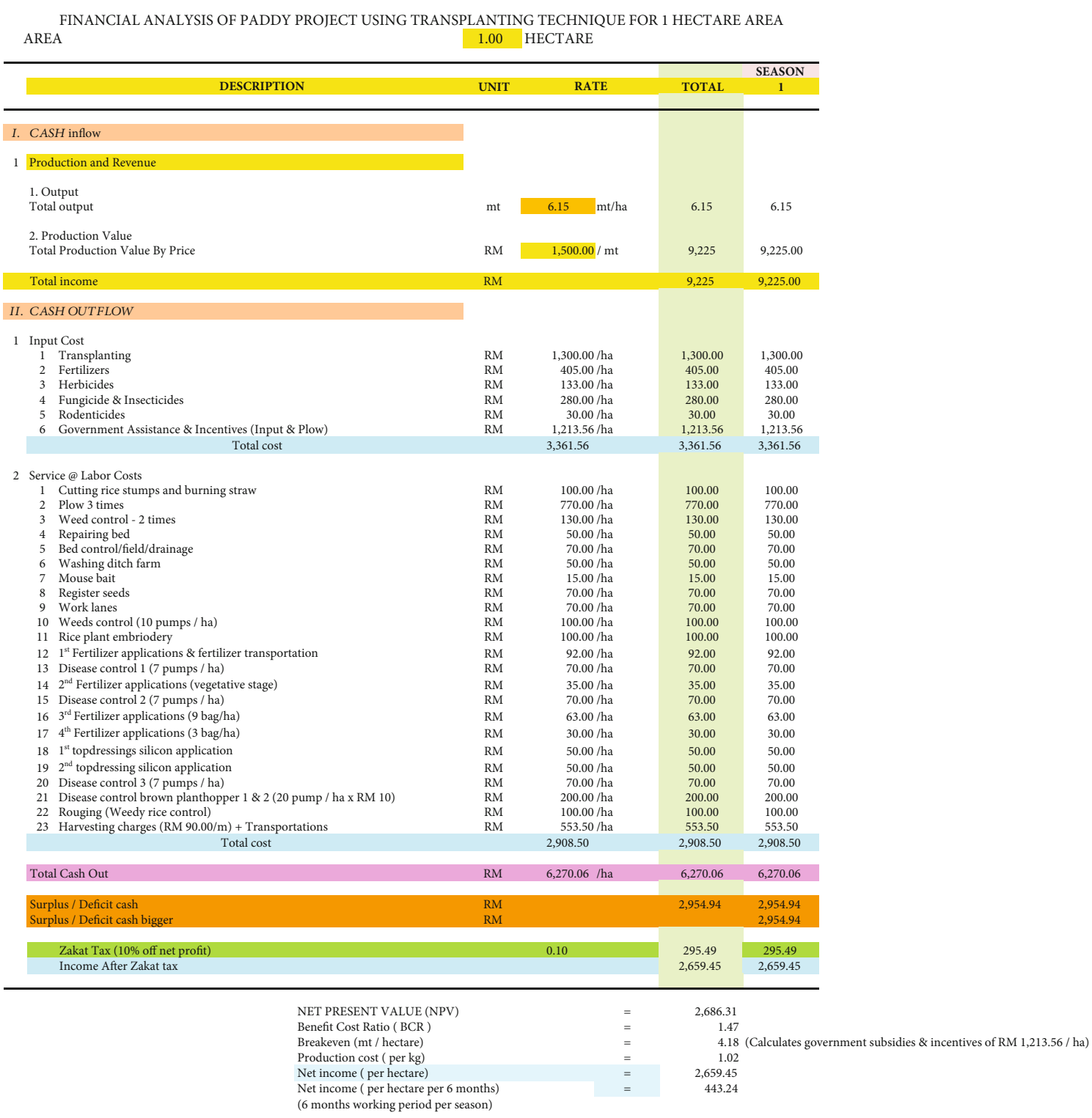

FIGURE 7: Financial analysis of paddy project using transplanting technique for one hectare of area (Si topdressing).

both $\mathrm{Si}$ treatments, respectively. It also improved the biomass partitioning, mostly to the culm and root, through improvements in photosynthetic efficiency [38]. The assimilation rates in photosynthetic leaves increased due to enhanced photosynthetic metabolites and enzyme activity, which directly improved grain production. The ratio of dry matter accumulation in roots to shoots with $\mathrm{Si}$ foliar applied treatments was greater than in the control plants, which clearly indicated the altered partitioning of resources within the rice plants. This might be due to the higher translocation of nutrients in roots, which influenced the movement of ions from the soil to the plant leaves. Similar results were reported by [39-41].

Using scanning electron microscopy (SEM), an extralong ladder-like structure and an intense number of silica bodies on the leaf structures for both Si treatments were observed.
Silica content could be well-deposited in the leaf epidermis of rice plants and form a thick layer as a support structure and for the protection of the leaf $[42,43]$. It was assumed that the consistently intense lignin accumulation in the leaf was for self-defence mechanism purposes; similar findings were observed by [12]. Interestingly, Si foliar applied treatments might alter the leaves stomatal width, thereby enhancing the stomatal aperture and improving photosynthetic efficiency for better dry matter accumulation [40, 41].

The strengthened culm sheath structures in Si-treated plants might be due to the thickness of the cell walls in the sclerenchyma and more vascular bundles in both the peripheral and the inner sections of the outer layers [44]. Similar findings with both Si treatments were found according to $[12,45]$. That indicates an efficient assimilated translocation process from root to shoot in Si treatments. 
Appendix C (Si foliar applied)

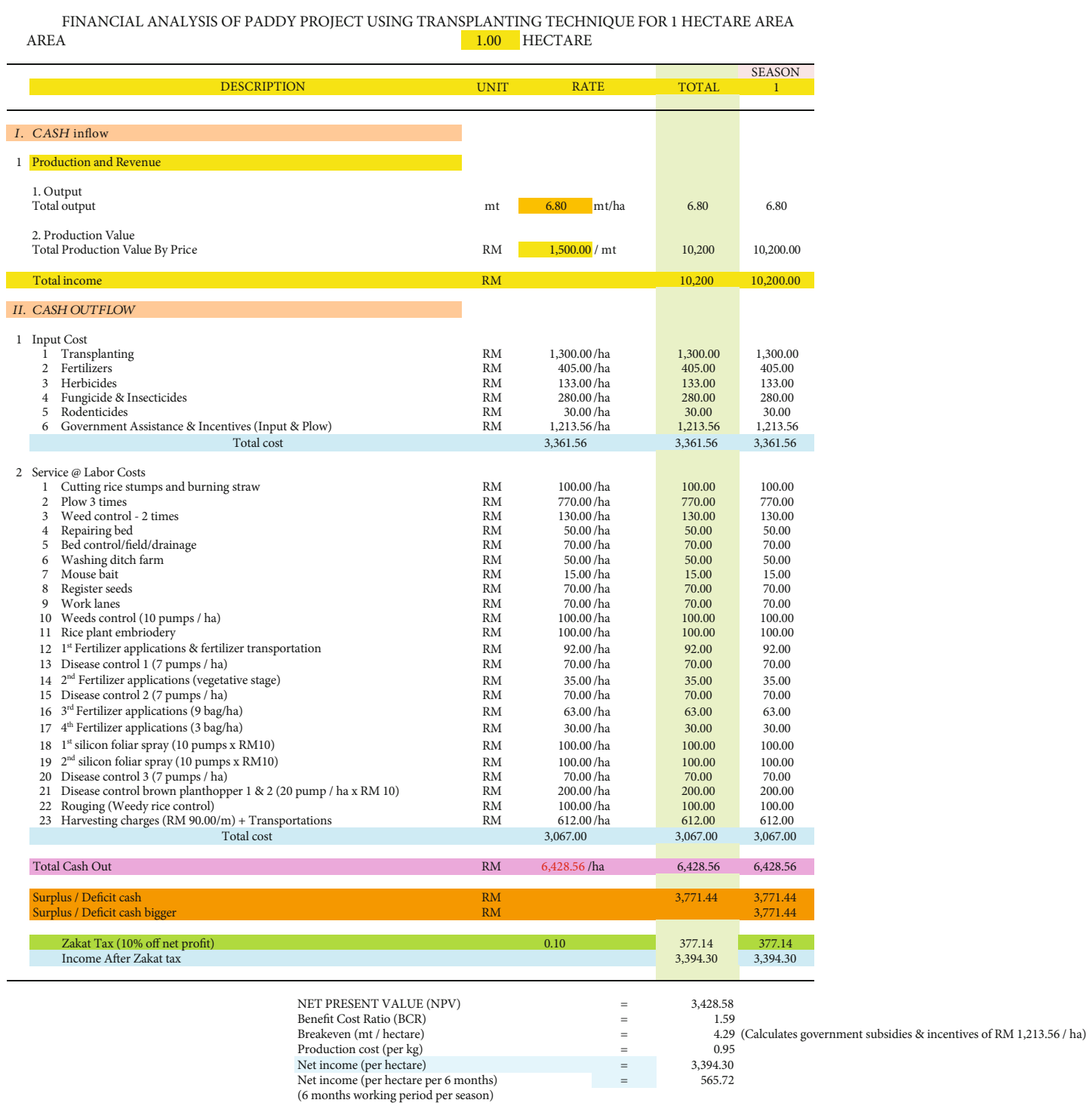

FIGURE 8: Financial analysis of paddy project using transplanting technique for one hectare of area (Si foliar applied).

Greater yield production with Si treatment showed that rice plants improve their photosynthesis and assimilated distribution [46, 47]. Spikelets per panicle and grain filling percentage were higher when Si was applied as foliar spray, compared to the other treatments. Compared to this parameter, the percentage of filled grain could potentially reveal more about the effects of $\mathrm{Si}$ supplementation as it is an indicator of sterility and fertility. Therefore, yield seems to be maximised when $\mathrm{Si}$ was supplied as foliar spray at the reproductive stage, which is also referred to as preheading [10]. Interestingly, BCR and NPV showed the better economic viability of adopting Si foliar applied treatments in rice plants. These results suggest the ability of Si foliar applied treatments to enhance farmers' income generation tremendously [47-53]. Thus, the Si foliar spray is the most suitable method of application and could be incorporated in combination with fungicides and insecticides to aid the supply of nutrients to crops in the form of sprays [10].
Further study should be conducted on the mechanism of Si foliar applied treatments on the plant uptake through the leaf and root; the enzymes and hormonal regulation related to yield improvement, such as sucrose synthase enzyme; and the molecular identification of genes associated with hormonal regulation.

\section{Conclusions}

Si foliar applied treatments affect the plant growth, physiological process, leaf and culm morphology, and the yield of rice. The adjustment of the leaves' stomatal width, the enhancement of the stomatal aperture, the more vascular bundles in the culm, and the efficient photosynthesis rate lead to better dry matter accumulation from root to shoot with Si foliar applied treatments. Therefore, rice yield production increased tremendously with a higher benefit-cost ratio and net present value. 


\section{Data Availability}

Regarding on data availability, we would like to declare that all data related to the work provided in the manuscript are submitted.

\section{Conflicts of Interest}

The authors declare that they have no conflicts of interests with regard to the publication of this paper.

\section{Acknowledgments}

The authors thank Mr. Said Hamid for participating in the field experiment. We further thank all ITAFoS staff especially Mrs. Nik Amelia Nik Mustapha, Mr. Muhammad Adzan Mastor, Mrs. Noraisyah Abdul Aziz, Mr. Zulhelmi Zulkifli, Mr. Mohammad Omar, Mrs. Azimah Su'ut, Mr. Said Hamid, and Mrs. Norhasimah Sulaiman for the assistance in the field, laboratory, and in administration. We are grateful to $\mathrm{Mr}$. Muhammad Faisal Mohd Zaid and Ms. Nur Zahirah Abdul Jalil for their assistances during this study. The authors thank the Ministry of Higher Education Malaysia (MoHE) for providing financial support through PadiU Putra Grant Scheme titled the accelerating rice food security and socioeconomics for rice farming communities (Vot no. 5526500).

\section{References}

[1] J. E. Sheehy and P. L. Mitchell, Rice and global food security: the race between scientific discovery and catastrophe. ACCESS NOT EXCESS - the search for better nutrition, Smith-Gordon, Cambridgeshire, United Kingdom, 2011.

[2] Ministry of Agriculture and Agro-based Industries, Malaysia, Paddy Statistics of Malaysia, Department of Agriculture, Malaysia, Putrajaya, Malaysia, 2013.

[3] S. Ismail, "Dasar dan polisi industri padi dan beras (Rice and rice industry policies and policies)," 2017, http://padi.mardi .gov.my/dokumen/slide/L1 Dasar dan Polisi Industri Padi dan Beras Shamsuddin Ismail (MOA).pdf [Accessed April 8, 2020].

[4] G. Miah, M. Y. Rafii, M. R. Ismail et al., "Inheritance patterns and identification of microsatellite markers linked to the rice blast resistance in $\mathrm{BC}_{2} \mathrm{~F}_{1}$ population of rice breeding," Bragantia, vol. 74, no. 1, pp. 33-41, 2015.

[5] F. Tanweer, M. Y. Rafii, K. Sijam et al., "Introgression of blast resistance genes (putative $\mathrm{Pi}-\mathrm{b}$ and $\mathrm{Pi}-\mathrm{kh}$ ) into elite rice cultivar MR219 through marker-assisted selection," Frontiers in Plant Science, vol. 6, no. 1002, pp. 1-11, 2015.

[6] N. K. Fageria, V. C. Baligar, and C. Ralph, Physiology of Crop Production, The Haworth Press, Binghamton, New York, 2006.

[7] V. Gowariker, V. N. Krishnamurthy, S. Gowariker, M. Dhanokar, and K. Paranjape, The Fertilizer Encyclopedia, John Wiley, New York, NY, 2009.

[8] J. Zhang, G. Li, Y. Song et al., "Lodging resistance characteristics of high-yielding rice populations," Field Crops Res., vol. 161, pp. 64-74, 2014.

[9] T. X. Cuong, H. Ullah, A. Datta, and T. C. Hanh, "Effects of silicon-based fertilizer on growth, yield and nutrient uptake of rice in tropical zone of Vietnam," Rice Science, vol. 24, no. 5, pp. 283-290, 2017.
[10] D. Dorairaj, M. R. Ismail, U. M. Sinniah, and K. B. Tan, "Silicon mediated improvement in agronomic traits, physiological parameters and fiber content in Oryza sativa," Acta Physiol. Plant, vol. 42, no. 3, p. 38, 2020.

[11] C. Zhang, L. Wang, W. Zhang, and F. Zhang, "Do lignification and silicification of the cell wall precede silicon deposition in the silica cell of the rice (Oryza sativa L.) leaf epidermis?," Plant and Soil, vol. 372, no. 1-2, pp. 137-149, 2013.

[12] D. Dorairaj, M. R. Ismail, U. R. Sinniah, and K. B. Tan, "Influence of silicon on growth, yield and lodging resistance of MR219, a lowland rice of Malaysia," Journal of Plant Nutrition, vol. 40, no. 8, pp. 1111-1124, 2017.

[13] K. Keegstra, "Plant cell walls," Plant Physiology, vol. 154, no. 2, pp. 483-486, 2010.

[14] G. Sposito, The Chemistry of Soils, Oxford University Press, New York, 1989.

[15] F. Á. Rodrigues, W. M. Jurick, L. E. Datnoff, J. B. Jones, and J. A. Rollins, "Silicon influences cytological and molecular events in compatible and incompatible rice- _Magnaporthe grisea_ interactions," Physiological and Molecular Plant Pathology, vol. 66, no. 4, pp. 144-159, 2005.

[16] E. Epstein, "The anomaly of silicon in plant biology," Proceedings. National Academy of Sciences. United States of America, vol. 91, no. 1, pp. 11-17, 1994.

[17] N. Mitani and J. F. Ma, "Uptake system of silicon in different plant species," Journal of Experimental Botany, vol. 56, no. 414, pp. 1255-1261, 2005.

[18] A. O. Lavinsky, K. C. Detmann, J. V. Reis et al., "Silicon improves rice grain yield and photosynthesis specifically when supplied during the reproductive growth stage," Journal of Plant Physiology, vol. 206, pp. 125-132, 2016.

[19] Z. W. Mo, S. Lei, U. Ashraf et al., "Silicon fertilization modulates 2-acetyl-1-pyrroline content, yield formation and grain quality of aromatic rice," Journal of Cereal Science, vol. 75, pp. 17-24, 2017.

[20] Y. Cai, S. Zhang, K. Cai, F. Huang, B. Pan, and W. Wang, "Cd accumulation, biomass and yield of rice are varied with silicon application at different growth phases under high concentration cadmium-contaminated soil," Chemosphere, vol. 242, p. $125128,2020$.

[21] J. F. Ma and E. Takahashi, "Silicon uptake and accumulation in plants," in Soil, Fertilizer, and Plant Silicon Research in Japan, pp. 73-106, Elsevier Press, Amsterdam, 2002.

[22] A.-A. Farnaz, K. Jugah, S. Ahmad, M. H. Ahmad Husni, and N. Abbas, "Effect of foliar and root application of silicon against rice blast fungus in MR219 rice variety," Plant Pathol. J, vol. 28, no. 2, pp. 164-171, 2012.

[23] M. Gao, Z. Zhou, H. L. Liu et al., "Foliar spraying with silicon and selenium reduces cadmium uptake and mitigates cadmium toxicity in rice," Sci. Total Environ., vol. 631-632, pp. 1100-1108, 2018.

[24] X. Q. Gan, L. G. Jiang, J. Y. Xu, D. F. Dong, and S. Q. Wei, "Characteristics and genotypic difference of silicon accumulation and distribution in rice," Plant Nutrition and Fertitizer Science, vol. 10, pp. 531-535, 2004.

[25] R. Clarke, "Understanding the drone epidemic," Computer Law and Security Review, vol. 30, no. 3, pp. 230-246, 2014.

[26] X. Y. Xue and Y. B. Lan, "Agricultural aviation applications in USA," Transactions CSAM., vol. 44, no. 5, pp. 194-199, 2013. 
[27] H. G. Jones and R. A. Vaughan, Remote Sensing of Vegetation: Principles, Techniques, and Applications, Oxford University Press, Oxford, 2010.

[28] S. Yoshida, "Physiological analysis of rice yield," in Fundamentals of Rice Crop Science, pp. 231-251, International Rice Research Institute, The Phillipines, 1981.

[29] R. Hunt, Plant Growth Analysis, Edward Arnold Ltd., London, 1978.

[30] N. C. Y. Norasma, Site-specific weed management using remote sensing. [PhD Thesis], School of Agriculture and Food Sciences, The University of Queensland, Queensland, 2016.

[31] A. Z. Ibrahim and C. Siwar, Kawasan Pengairan Muda: Merentasi Masa Menyangga Keselamatan Makanan Negara, Jurnal Pengurusan Awam, 2012.

[32] C. U. Nwaobiala and O. M. Adesope, "Economic analysis of small holder rice production systems in Ebonyi State South East, Nigeria," Russian Journal of Agricultural and SocioEconomic Sciences, vol. 23, pp. 1-10, 2013.

[33] C. Ingabire, A. R. Bizoza, and J. Mutware, "Determinants and profitability of rice production in Cyabayaga Watershed, Eastern Province, Rwanda," Rwanda Journal, Series H: Economics and Management., vol. 1, pp. 63-75, 2013.

[34] J. Feng Ma, N. Yamaji, and N. Mitani-Ueno, "Transport of silicon from roots to panicles in plants," Proceedings of the Japan Academy, Series B, vol. 87, no. 7, pp. 377-385, 2011.

[35] M. A. Amirul, J. Abdul Shukor, M. Y. Rafii, and A. H. Azizah, "Effect of salinity on biomass yield and physiological and stem-root anatomical characteristics of Purslane (Portulaca oleracea L.) accessions," BioMed Research International, vol. 2015, 15 pages, 2015.

[36] R. Alcázar, T. Altabella, F. Marco et al., "Polyamines: molecules with regulatory functions in plant abiotic stress tolerance," Planta, vol. 231, pp. 237-1249, 2011.

[37] S. Chauhan, R. Darvishzadeh, M. Boschetti, M. Pepe, and A. Nelson, "Remote sensing-based crop lodging assessment: current status and perspectives," J. Photogramm. Remote Sens., vol. 151, pp. 124-140, 2019.

[38] J. Guo, W. Xu, X. Yu et al., "Cuticular wax accumulation is associated with drought tolerance in wheat near-isogenic lines," Frontiers in Plant Science, vol. 7, no. 1809, pp. 1-10, 2016.

[39] H.-Y. Kim, S.-S. Lim, J.-H. Kwak et al., "Dry matter and nitrogen accumulation and partitioning in rice (Oryza sativa L.) exposed to experimental warming with elevated $\mathrm{CO}_{2}$," Plant and Soil, vol. 342, no. 1-2, pp. 59-71, 2011.

[40] A. Puteh and M. M. A. Mondal, "Salinity stress during booting and heading stages affects yield in rice," Life Science Journal, vol. 11, no. 6, pp. 223-226, 2014.

[41] B. Zulkarami, D. Deivaseeno, M. S. Halimi, O. Muhammad Husni, Y. Nazmin, and I. Mohd Razi, "Water stress affects growth, biomass partitioning, grain filling and productivity of MR219, a high yielding rice variety of Malaysia," Int. J. Agric. Environ. Bio-Res., vol. 3, no. 4, pp. 410-426, 2018.

[42] D. R. Piperno and D. M. Pearsall, "The Silica Bodies of Tropical AmericanGrasses: Morphology, Taxonomy, and Implications for Grass Systematics and Fossil Phytolith Identification," in Smithsonian Contributions to Botany, Smithsonian Institution Press, Washington, 1998.

[43] J. D. Meunier, D. Barboni, M. Anwarul Haq et al., "Effect of phytoliths for mitigating water stress in durum wheat," The New Phytologist, vol. 215, no. 1, pp. 229-239, 2017.
[44] S. G. Kim, K. W. Kim, E. W. Park, and D. Choi, "Silicon induced cell wall fortification of rice leaves: a possible cellular mechanism of enhanced host resistance to blast," Phytopathology, vol. 92, no. 10, pp. 1095-1103, 2002.

[45] G. S. Chaturvedi, C. H. Misra, O. N. Singh, C. B. Pandey, V. P. Yadav, and A. K. Singh, "Physiological basis and screening for tolerance for flash flooding," in Rainfed Lowland Rice, Agricultural Research in High Risk Environment, K. T. Ingram, Ed., pp. 79-96, International Rice Research Institute, Los Banos, 1995.

[46] P. Counce and K. Gravois, "Sucrose synthase activity as a potential indicator of high rice grain yield," Crop Science, vol. 46, no. 4, pp. 1501-1507, 2006.

[47] B. Zulkarami, D. Dorairaj, S. Halimi Mohd, and I. Mohd Razi, "Regulation of sucrose synthase and its association with grain filling in spermine-treated rice plant under water deficit," Journal of Plant Interactions, vol. 14, no. 1, pp. 464-473, 2019.

[48] M. Reynolds, J. Foulkes, R. Furbank et al., "Achieving yield gains in wheat," Plant, Cell and Environment, vol. 35, no. 10, pp. 1799-1823, 2012.

[49] M. Ashraf, N. A. Akram, F. Al-Qurainy, and M. R. Foolad, "Drought tolerance: roles of organic osmolytes, growth regulators and mineral, nutrients," Advances in Agronomy, vol. 111, pp. 249-296, 2011.

[50] P. K. Mohapatra, R. Panigrahi, and N. C. Turner, "Physiology of spikelet development on the rice panicle: is manipulation of apical dominance crucial for grain yield improvement?," Advances in Agronomy, vol. 110, pp. 333-359, 2011.

[51] B. Zulkarami, Q. A. Panhwar, I. Mohd Razi, M. S. Halimi, and M. M. A. Mondal, "An alternative and quicker strategy to improve rice (Oryza sativa) yield through application of phytohormones," Trans. Malaysian Soc. Plant Physiol., vol. 22, pp. 180-184, 2014.

[52] N. K. Fageria, F. M. P. Barbosa, A. Moreira, and C. M. Guimaraes, "Foliar fertilization of crop plants," Journal of Plant Nutrition, vol. 32, no. 6, pp. 1044-1064, 2009.

[53] K. Girma, K. L. Martin, K. W. Freeman et al., "Determination of optimum rate and growth stage for Foliar-Applied phosphorus in corn," Communications in Soil Science and Plant Analysis, vol. 38, no. 9-10, pp. 1137-1154, 2007. 